\title{
THE ASSIGNEE OF CONTRACT RIGHTS AND HIS PRECARIOUS SECURITY
}

\author{
GRANT GILMORE广
}

\section{Professor Corbin}

For several years after I began teaching the first-year course in Contracts at the Law School, Professor Corbin graciously came, once each year, to teach one class. These were great occasions: in addition to the students officially enrolled, as many more attended as could squeeze their way into the classroom. I told my own students that, in Professor Corbin's classes, a person called on to engage in Socratic dialogue with the instructor stood up in the full glare of publicity instead of remaining seated in comfortable anonymity. In advance of the class I gave Professor Corbin the names of half a dozen students whom I conceived to be among the brightest and hoped for the best. Fortunately there were no scandals, and, year by year, Professor Corbin seemed to be content with the current crop of law students.

Having no use for sentimental reminiscence, Professor Corbin would teach, with undiminished vigor and skill, for fifty minutes. The one indulgence which he permitted himself was that, at the end, he would read a passage from The Nature of the Iudicial Process. Cardozo's description of his own search for certainty in the law, and his ultimate realization that certainty is not the goal, was evidently deeply meaningful to Professor Corbin. I have thought, listening to him read Cardozo's words, that the quest which the great judge so movingly describes had been the great scholar's quest as well.

The words with which Professor Corbin chose to conclude the last class which he taught at the Yale Law School were these:

I was much troubled in spirit, in my first years upon the bench, to find how trackless was the ocean on which I had embarked. I sought for certainty. I was oppressed and disheartened when $I$ found that the quest for it was futile. I was trying to reach land, the solid land of fixed and settled rules, the paradise of a justice that would declare itself by tokens plainer and more commanding than its pale and glimmering reflections in my own vacillating mind and conscience. I found "with the voyagers in Browning's 'Paracelsus' that the real heaven was always beyond." As the years have gone by, and as I have reflected more and more upon the nature of the judicial process, I have become reconciled to the uncertainty, because I have grown to see it as inevitable. I have grown to see that the process in its highest reaches is not discovery, but creation; and that the doubts and misgivings, the hopes and fears, are part of the travail of mind, the pangs of death and the pangs of birth, in which principles that have served their day expire, and new principles are born.*

$\dot{i} W$ illiam K. Townsend Professor of Law, Yale Law School.

The article which follows is extracted from a fortheoming treatise on the law of personal property security transactions, to be published by Little-Brown \& $\mathrm{Co}$.

Acknowledgment of indebtedness is gratefully made to Dean Bayless Mranning of the Stanford Law School, who made available to me an unpublished memorandum on the problems of assignment of contract rights which he prepared some years ago. Dean Manning is not, of course, responsible for my errors, omissions or conclusions.

It may clarify some of the discussion of the drafting of Article 9 of the Uniform Commercial Code to point out that I served as Associate Reporter and Reporter for that Article from 1946 to 1952. 


\section{INTRODUCTION}

Security assignments of executory contract rights have been widely used only in recent years. The assignment of "moneys due and to become due" under a building or construction contract has been institutional for nearly a hundred years: the contractor (or subcontractor) at the outset assigns to his bank the money he will earn by future performance as security for the present loan which enables him to undertake the job. But for a long time the pattern was not customary in any other context. The financing of government procurement contracts during World War II probably furnished the major stimulus for the spread of the device into other industries. The sudden and enormous increase of industrial production dictated by the war effort required a huge volume of new financing. That task could have been undertaken by the United States, but was instead delegated, to the extent possible, to private financing institutions. As one method of encouraging the banks to do their bit, the United States, reversing its long-standing policy, agreed, by the Assignment of Claims Act of 1940,1 to recognize assignments of moneys to become due under contracts with the federal government or its agencies. Thus, during the 1940's banks and their counsel became extensively familiar, albeit in an abnormal situation, with some of the incidents of lending against this novel type of collateral.

During the past several years, discussions of some of the problems presented by the use of long-term contracts as security have begun to appear in the law reviews. ${ }^{2}$ These pioneering articles, mostly by practitioners who are immediately involved in finding answers to questions which had not even been posed, let alone answered, by the previous literature, are of enormous interest. They are principally concerned with transactions which are carried out at the highest level of corporate finance. For example, a solvent corporation, of high credit standing, may desire to branch out into some new activity, which will frequently be subsidiary to its main enterprise. The corporation could perfectly well raise or borrow the necessary funds on its own credit, but for tax, accounting or other reasons prefers not to. Instead it creates a new corporation whose principal or only function will be carrying out the new activity and whose principal or only asset will be a long-term contract with the high-credit parent. ${ }^{3}$ The

*Cardozo, The Nature of the Judicial Process 166-67 (1921).

1. 54 Stat. 1029 (1940), 31 U.S.C. § 203 (1958).

2. Gustin, Fintancing by Contract and by Lease - Some Considerations, 13 PkoceenIngs of the Ass'n of Life Ins. Counsel 685 (1957); Comment, Contract Rights as Commercial Security: Present and Future Intangibles, 67 YALE L.J. 847 (1958); Wilkinson, Borrower's Contracts as Long Term Loan Security, 17 Bus. Law. 1018 (1962); Coogan, Intangibles as Collateral Under the Uniform Commercial Code, 77 Hanv. L. Rev. 997 (1964).

3. Mr. Coogan uses as an illustration the construction of a mill to manufacture paper for the purpose of performing a long-term requirements contract between Paper Company and Newspaper Company. Either Paper Company or Newspaper Company could provide for the mill but instead they collaborate in creating a "borrowing entity" to construct and operate the mill. Paper Company contracts with the "entity" to sell pulp to it; Newspaper Company contracts with the "entity" to buy paper from it. The "entity's" rights under the two contracts will be the security for a bank loan. Coogan, stupra note 2, at 1004. 
long-term contract will become the principal or only security for a loan made, in form, to the low-credit subsidiary but, in reality, on the credit of the parent. The point of the operation is to give the lender the benefit of the parent's resources without creating an obligation which will show on the parent's balance sheet: achieving this involves a certain amount of legal fiction but no trickery or deceit, at least among the parties to the financing transaction.

The law of secured financing has heretofore been a sort of paradise for specialists. The nineteenth century developed inventory financing devices such as "trust receipts" and "factor's liens" to avoid the problem of inherent fraud which courts saw in a seller's or mortgagor's retention of control over his goods. ${ }^{4}$ In the twentieth century lenders had to avoid the rule of Benedict $\%$. Ratner, ${ }^{5}$ which required the lender, on somewhat the same theory as the nineteenth century inventory mortgage cases, to police his debtor's affairs if he wished to secure his debt upon accounts receivable. Although the rule of Bcnedict v. Ratner is abolished by the Uniform Commercial Code and seems to be on the wane in non-Code states, it may be that the pre-Code patterns of receivables and inventory financing will, nevertheless, continue: the lender, who is no longer required as a matter of law to police his borrower's affairs, may go on doing so for his own peace of mind. It is also possible, however, that lenders - let us say, "country banks" - who do not have the painfully acquired expertise of the specialists will be tempted to take advantage of the Code's lowering of barriers. We may begin to see term loans made on the security of all a borrower's assets - his equipment, his inventory, his present and future receivables and contract rights - with no attempt by the lender to police or control. We have noted that the first serious discussions of what we may call "contract rights financing" have been by specialists for specialists. In the earlier

4. That the mortgagor should be given "complete power and dominion" over the mortgaged property was somehow "inconsistent" with the very idea of a mortgage. This language is found in the argument of counsel in Mitchell v. Winslow, 17 Fed. Cas. 527,530 (No. 9673) (C.C.D. Maine 1843). In Mitchell v. Winslow, Justice Story, silting on the circuit court, held that an inventory mortgage, which had been properly recorded, was valid against an "assignee in bankruptcy" under the short-lived Bankruplcy Act of 1841. Justice Story's views, however, did not prevail - or did not prevail until the following century and then in a different guise.

By the end of the century it was clear that the controversy over the inventory mortgage could not be resolved. See, e.g., Pierce, Fraudulent MIortgages of Mercinandise (1892); Cobbey, Chattel Mortgages (1893); Jones, Chatter Mortgages (4th ed. 1894). Pierce was violently opposed to inventory mortgages, Cobbey strongly favored them, Jones took a neutral position. The three authors were in wild disagreement on the number of states which did, and which did not, hold such mortgages fraudulent "as a matter of law". See PIERCE, ch. III-VII; 1 COBbEY § 309; JoNes § 415.

By this time, however, counsel had developed the devices referred to in the text to achieve the same effect by different means.

5. 268 U.S. 353 (1925).

An excellent illustration, from the recent case law, of "how to comply with Bencdict", is Matter of New Haven Clock \& Watch Co., 253 F.2d 577 (2d. Cir. 1958). 
great mutations of security law, the solutions that were eventually arrived at were, and remained, specialists' solutions. In the current mutation, however, it is entirely within the realm of possibility that the specialists will soon be left behind and that the amateurs will take over. In that eventuality, we may assume that the new law which will develop will be, in tone and substance, significantly different from the highly professionalized law of trust receipts and accounts receivable financing.

We may state the problem which will be examined in the following pages this way: to what degree is an assignee of executory contract rights protected against defenses arising under the contract and against subsequent acts of the contracting parties which, if they are binding on the assignee, wotuld jeopardize his position by diminishing the value of his security or by destroying it altogether? Or, to put the point more concretely: how much security, or what kind of security, does a bank get when it makes a loan to a manufacturer who has a long-term contract to supply a buyer's requirements, the principal or only security for the loan being the moneys which will become due as deliveries are made under the requirements contract?

It is entirely clear that there are many ways in which our hypothetical bank could protect itself if it wanted to. It could require, as a condition of making a loan to the manufacturer, an express promise from the requirements buyer that the buyer's requirements will not decrease during the loan period, that the buyer will not attempt to modify the contract without the bank's consent, that the buyer will pay the bank whether or not the goods are delivered ("take or pay") ${ }^{6}$ and whether or not goods delivered are defective. Or, going beyond the realm of contract, the bank could require that the voting stock of both corporations be put in a trust subject to the bank's control, put its own nominees on the boards of directors, and so on. Of course, in any given situation, the bank might or might not have the economic power to impose such conditions or, if it had the power, might or might not choose to exercise it. In any case, our present inquiry is not, what can the bank do but rather, what does the bank get if it takes, as security, merely an assignment of the moneys which will become due if and when the requirements contract is performed? It may be that a clearer understanding of what the bank gets will be helpful to the prudent bank officer in deciding whether to make the loan against such security, or to make the loan only if additional safeguards to protect the bank are imposed, or not to make the loan at all.

If these problems become the focus of litigation during the next generation, the Uniform Commercial Code will provide the statutory framework within which they will be decided. In the course of our discussion we shall have occasion to consider Code provisions drawn from the Articles on Sales and on Secured Transactions. Draftsmen are most apt to be right, or at least helpful,

6. On the so-called "take or pay" contract, see the articles by Wilkinson and Coogan cited note 2 supra. 
when they are dealing with problems which have, over a period of time, been the subject matter of a considerable amount of litigation - with problems which have, so to say, reached a sort of legal maturity or ripeness. In drafting the Article on Secured Transactions, for example, it was possible to approach the problems of inventory and short-term receivables financing with a fair degree of confidence: the process of drafting was mostly one of setting down, in a statutory formulation, the solutions arrived at under the pre-Code law. If, on the other hand, a draftsman has to deal with problems which can hardly be guessed at, arising under a vaguely perceived shift in practice, which may or may not prove to be permanent, it will only be by the purest of accidents or the most divine of inspirations that his contribution will be either right or helpful.

Although the Code contains a number of distinctly relevant provisions, it does not cover the whole range of our problem. The pre-Code case law will continue to be, in many situations, persuasive and relevant. We cannot escape, therefore, the necessity of making preliminary investigations of an historical or archaeological nature into some of the more obscure areas of the law of contracts.

The following discussion will be devoted principally to the assignment of rights to the payment of money to be earned by performance under contracts which are, wholly or in part, executory at the time the assignment is made. It is assumed, and there is no modern authority to the contrary, that such rights can be effectively assigned. Whether or not it was ever true that "choses in action" could not be assigned at all, or that they could be assigned but only in such a way that the assignee received a "merely equitable interest" (whatever that may have meant), it is assumed here that the assignee's interest can only be described as "legal". No attention will be paid to possible distinctions between "partial" and "total" assignments: there is no modern authority" which suggests that the rights of a "partial" assignee are in any way inferior to, or different from, the rights of a "total" assignee. Under Article 9 of the Code, the assignee, in order to perfect his interest against third parties (and the assignor's trustee in bankruptcy) will be required to file a notice of his assignment, but that has nothing to do with the relationship of assignor, assignee and obligor. To the extent that perfection of the assignee's interest may be relevant to our discussion, it will be assumed that a proper notice or financing statement has been filed.

\section{Clearing Away Sone Underbrush}

There are two preliminary points that may be disposed of before we take up the main thread of our discussion. These have to do with "conditional," as distinguished from "absolute," assignments and with "third party beneficiaries" as distinguished from "assignees." It will be suggested that neither distinction is, in this context, helpful. 


\section{The theory of the "conditional" assignment}

It is sometimes suggested that an obscure common-law distinction between "absolute" and "conditional" assignments may be relevant to our discussion.7 Following an assignment of future proceeds which is merely "conditional," if the condition has not occurred, the contracting parties would remain free to modify or rescind their contract without the assignee's consent despite the assignment and notification. On the other hand, if the assignment, although it covers future proceeds, is "absolute", then, after notification, the assignee would be in control of the situation so that the assignor and obligor could no longer prejudice his rights without his consent. Thus, by a simple drafting trick, financing assignees could immensely improve their situation.

The term "conditional assignment" is properly used to describe a transaction in which the assignee's right to the fruits of his assignment is conditioned on the occurrence of some event. Professor Corbin, for example discusses "conditional assignments" at some length, using the term as a merely descriptive reference. $^{8}$ The substantive point which Corbin makes is that, whatever the position of the early common law may have been, such assignments are today entirely proper, valid, legal and enforceable. The condition may be the assignor's performance of an executory contract, or it may be the assignor's default under his loan agreement with the assignee, or it may be anything in the world which the reader may wish to hypothesize. Security assignments of executory contract rights might be described as doubly conditional : conditional both on performance and on default. The only reason for so describing them would be to make the same point that Corbin makes: the conditions, separately or together, do not in any way affect the validity of the assignment. ${ }^{\circ}$ When Corbin goes on to discuss the question of the contract defenses which the obligor may assert against the assignee, he makes no distinction between conditional and absolute assignments $:{ }^{\mathbf{1 0}}$ the defenses which may be asserted against an assignee whose right was originally subject to a condition are, apart from the condition itself, exactly the same as those which may be asserted against an assignee whose right was not conditional.

The conditional-absolute distinction has in recent years been invoked as helpful in a couple of unlikely situations. In In re Neze York, New Haven of Hartford Railroad Company ${ }^{11}$ Judge Hincks held that an assignment by the Railroad to the Reconstruction Finance Corporation of the proceeds of an executory contract was not invalid under the rule of Benedict v. Ratncr. In

7. See Wilkinson, supra note 2 , at 1022 .

8. 4 CORBIN, CoNtracts $\$ \S 875-77$ (1951).

9. In Maloney v. John Hancock Mut. Life Ins. Co., 271 F.2d 609 (2d Cir. 1959), Judge Hincks commented that, "The parties to the transfer in this case plainly intended to make a present transfer of all Eastern's interest in the policy subject to a double condition ...." The court saw nothing wrong, or even odd, in the idea of "a present transfer ... subject to a double condition." Id. at 614 .

10. 4 CoRBIN, Contracts $\$ 892$ (1951).

11. 25 F. Supp. 874 (D. Conn. 1938). 
part, Judge Hincks based his holding on the ground that since the railroad's assignment to RFC was subject to a "definitely stated event" (i.e., the railroad's default under its loan agreement), it was in that respect unlike the assignment in Benedict, and therefore was not invalidated by the Benedict rule. Whatever the merits of that subtle distinction may be, the result in the New Haven case seems to have been generally approved, and the case may be taken as symbolizing a turn in the tide, which was thereafter set against any further expansion of Benedict. It was possible to cite the New Haven case for the proposition that Benedict did not apply to conditional assignments such as, perhaps, an assignment of rents under a real estate mortgage or an assignment to secure a surety's contingent liability under a performance bond.

Unfortunately, the "conditional assignment" idea, which seemed so helpful as a way of avoiding Benedict, led to trouble on another front. If the assignee had no rights under the assignment until the condition occurred (default under the loan agreement, for example) should not the "maturing" of his rights be looked on as a transfer of property for an antecedent debt and, thus, vulnerable to attack in bankruptcy proceedings as a preference voidable under section 60 ? To meet that attack, it was necessary to argue that cases like New Haven which stressed the "conditional" nature of security assignments, did not really mean that there was not also, at the time of the assignment, a present transfer of rights to the assignee. ${ }^{12}$ A commentator has suggested that what seems to be coming out of these conflicting pressures is a new or "equivocal" form of assignment - future and conditional for some purposes, present and absolute for others. ${ }^{13}$

It is hoped that the whole distinction may be forgotten, except in the descriptive or historical sense that Professor Corbin uses it. The rule in Benedict has lost its former vigor $:^{14}$ it is no longer necessary (if it ever was) to invent a theory of conditional assignment as a way of avoiding the rule. And the conditional assignment theory merely adds additional confusion to the already confused case law under section 60 of the Bankruptcy Act.

In the succeeding sections we will discuss the effectiveness against assignees of contract defenses, modifications and rescissions without resort to the distinction between absolute and conditional assignments. The cases make no such distinction. There is simply no reason to believe that an assignee of executory rights, whose assignment is in form present and absolute, will be (or should be) somehow insulated from defenses and modifications which would be good against him if his assignment were in form future and conditional.

\section{The "Third Party Beneficiary" Caper}

It has occasionally been suggested that a lender whose security consists of moneys to become due under an executory contract will be or may be or

12. See Malone v. Bolstein, 151 F. Supp. 544 (N.D.N.Y. 1956), aff'd, 244 F.2d 954 (2d Cir. 1957), in which the argument was successful. Judge Brennan's opinion for the district court reviews the "conditional assignment" cases.

13. Wilkinson, supra note 2 , at 1023 .

14. See text following note 5 supra. 
should be in a stronger position against the contract obligor if he can describe himself as a third party beneficiary of the contract rather than as an assignee. ${ }^{10}$ Some odd provisions of the Restatement of Contracts seem to give a certain weight to this suggestion. ${ }^{\mathbf{1 6}}$

The Restatement uses the term "incidental beneficiary" to describe a person who, although he may be in some sense benefitted by the performance of a contract to which he is not a party, has no right to sue on it. The terms "donee beneficiary" and "creditor beneficiary" are used to describe the classes of people who are entitled to sue as third party beneficiaries of contracts to which they are not parties. ${ }^{17}$ The definitions of the two terms are not uncomplicated, but the basic distinction is what the words suggest: the donee beneficiary receives a gift; the creditor beneficiary receives satisfaction of an obligation. The Restatement assumes that the beneficiary, whether donee or creditor, is in some relationship with the promisee who seeks, by procuring the promise of the other party, either to make a gift or to satisfy an obligation.

It would be entirely possible to set up a financing transaction so that it fitted within the Restatement's third party beneficiary construct. Assume that a lender makes an advance to a seller which is to be repaid by the buyer's remittance of the purchase price. There is no difficulty in drafting the loan agreement and sales contract so that the lender is the creditor beneficiary of the buyer's promise to pay the seller for goods delivered. Is there, however, any conceivable reason why the lender should be better off if he were described as "creditor beneficiary" than if he were described as "assignee"? If there is, the law is headed straight toward madness.

The Restatement, which, as we shall see presently, says nothing about the power of the obligor and assignor to modify or rescind their contract after as: signment and notification, goes into detail about the "variation of duties to beneficiaries by promisor and promisee. Section 142 states a flat rule that "the duty of the promisor to the donee beneficiary cannot be released by the promisee or affected by any agreement between the promisee and the promisor . . . ." Section 143 states a more compilcated rule with respect to the creditor beneficiary:

A discharge of the promisor by the promisee in a contract or a variation thereof by them is effective against a creditor beneficiary if, a) the creditor beneficiary does not bring suit upon the promise or otherwise materially change his position in reliance thereon before he knows of the discharge or variation, and

b) the promisee's action is not a fraud on creditors.

The intended relationship between paragraphs (a) and (b) is elucidated in the Comment. If the promisee does not have assets sufficient to satisfy all his

15. See Comment, Contract Rights as Commercial Security: Present and Future Intangibles, 67 Y ALE L.J. 847, 888-92 (1958).

16. The Restatement devotes a sequence of fifteen sections ( $\$ \$ 133-47$ ), which makes up Chapter 6, to the "Contractual Rights of Persons Not Parties to the Contract".

17. Restatement, Contracts $\$ 133$ (1962). 
creditors, then his attempted discharge of the promisor, or other variation of the contract in a manner adverse to the beneficiary's interest, is a "fraud on creditors" and ineffective against the beneficiary whether or not the beneficiary has acted in reliance on the promise or even knows of it [subsection (b)]. But even where the promisee is solvent, no discharge or variation is "effective" against the beneficiary after the beneficiary has either brought suit on the promise or materially changed his position in reliance on it [subsection (a)].

In the terms of our illustration of the lender who finances a sales transaction, his making an advance to the seller would "materially change his position in reliance" on the underlying contract. Thereafter, no "variation" of the buyer's obligation would be "effective" against the lender. (Even under the Restatement the lender would of course be subject to the buyer's contract defenses if the seller did not perform the sales contract: section 140 preserves such defenses against both donee and creditor beneficiaries.)

One mystery about the Restatement provisions is why the "variation" rule should be more favorable to donees than to creditors. It is said that the chief authority for the "donee" rule of section 142 was life insurance cases of fairly old vintage. ${ }^{18}$ In fact it is, and long has been, standard practice to provide in life insurance policies that the insured may change the beneficiary: thus the rule of section 142 has no effect even within what might be called its own bailiwick. Nor have the courts shown much sympathy for the rule that the donee's rights vest immediately in any other context.10

Another mystery is why the Restatement, which ignored the problem of modification and rescission in the context of assignment, should have seen the same problem in such sharp focus in the context of third party beneficiaries. It is a reasonable hypothesis that the life insurance cases, which inspired the draftsmen to write section 142 , were also responsible for section 143 . Once the draftsmen had been alerted to the problem, and had stated a rule to solve it, with respect to the class they had named "donee beneficiaries", it was obvious that the same problem existed with respect to the other class of beneficiaries, so that a rule had to be stated for creditors too.

The "material change of position" rule of section 143 has fared a good deal better in the court of public opinion than the "immediate vesting" rule of section 142.20 In appraising the merits of the "material change of position"

18. Page, The Power of the Contracting Parties to Alter a Contract for Rendering Performance to a Third Person, 12 WIs. L. Rev. 141 (1937). Professor Page's article, which is a brilliantly effective attack on the Restatement provisions, contains an apparently exhaustive collection of cases involving both donee beneficiaries and creditor beneficiaries.

19. The case law is reviewed in Note, The Third Parly Beneficiary Concept: $A$ Proposal, 57 CoLuxr. L. REv. 406 (1957). Two cases of exceptional interest are AleCulloch v. Canadian Pac. Ry., 53 F. Supp. 534 (D. Minn. 1943); and In re Duluth S.S. \& A. Ry., 58 F. Supp. 733 (D. Minn. 1945) ; both cases dealt with the same intricate transaction.

20. The Columbia Note, supra note 19, proposes that the "material change of position" rule be applied to donees and creditors alike. 
rule, however, little attention has been paid to the necessity or desirability of distinguishing between situations where the promisor-promisee transaction has been executed at the time the promise is made to, or for the benefit of, the third party and situations where the promisor-promisee transaction is still executory. To go back to our sales financing transaction, it might make a considerable difference whether the finance company made its advance after the goods had been delivered and accepted or while the sales contract was still a paper transaction awaiting future performance.

Most of the third party beneficiary case law which has discussed the question of modification or rescission and announced a "material change of position" rule has involved situations where the promisor-promisee transaction was executed, not executory. Even so, there is not, and never has been, much case law which has even discussed the question. Until recently the principal issues in third party beneficiary litigation have been whether the doctrine itself was accepted in the jurisdiction and whether, assuming that the doctrine had been accepted, the plaintiff was within the class of beneficiaries entitled to stue on contracts to which they are not parties. The issues of defenses and, to use the Restatement terminology, variations have not been much, or carefully, analyzed. Nor is the "material change of position" rule of universal authority. For example, several Western states have long had a statutory provision, derived from the Field Code, which reads: "A contract made expressly for the benefit of a third person may be enforced by him at any time before the parties thereto rescind it."21

Third party beneficiary law and assignment law do not of course overlap at all points, although they do overlap at some points. Where they do, it is helpful to recognize the overlap. By what appears to have been a series of accidents, the draftsmen of the Restatement overlooked the modification and rescission problem in their treatment of assignments, but, when they came to third party beneficiaries, stated, restated or, perhaps, overstated a rule which may go too far in protecting beneficiaries against subsequent change. Where the subject matter of a transaction is a transfer of contract rights as security, Restatement section 143 seems to confer on the transferee who describes himself as a "creditor beneficiary" greater rights than he ever had as a common-law assignee and, arguably, greater rights than he ever had, apart from the Restatement, as a third party beneficiary. At all events it could hardly be seriously argued that the quantum of his rights should vary with the label which he chooses to attach to the transaction.

In a state which has enacted Article 9 of the Code, it should make no difference whether the lender describes himself as assignee, third party beneficiary, Supreme Exalted Potentate, Lord of the Three Worlds or whatever other title his fancy may suggest. Under section 9-102(1), the Article applies "to

21. Page, supra note 18 , at 166 , says that the statutory provision, which was $\$ 749$ of the Field Code, had been adopted in California, Montana, North Dakota, Oklahoma and South Dakota. 
any transaction (regardless of its form) intended to create a security interest in personal property ...." The term "security interest" is defined [section 1-201(37)] to mean "an interest in personal property which secures payment or performance of an obligation." The essential purpose of Article 9 was to bring to an end the long period of fragmentation of personal property security law. ${ }^{22}$ With the enactment of Article 9, the possibility of creating new "independent security devices" is no longer open to counsel, however imaginative and astute. If a transaction "creates a security interest", a determination which is ultimately left to the courts under the sweeping definition of section 1-201(37), the rules of the Article apply, no matter what virtuosity of language may have been lavished on the documents. Even apart from Article 9, it is unlikely that courts would have been greatly impressed by the "third party beneficiary" trick. Under Article 9, that line of argument is no longer tenable: a security transferee who is a "third party beneficiary" is quite as much a secured party as one who is an "assignee".

\section{The Assignee and the Obligor's Defenses}

Assignment law harshly requires a contract obligor to determine, at his own risk, the validity of assignments of claims against him. The obligor's consent to such an assignment is not, and perhaps never has been, required. Until he has been notified of an assignment, he is protected in making payments to, and otherwise dealing with, the assignor, his original creditor. But from the instant he receives notification of assignment, his situation is drastically changed. The assignment of which he is notified may, of course, be valid or invalid. What purports to be an assignment may be a forgery or may have been extorted by duress or fraud or may have been procured from someone who lacked capacity to contract or, at all events, authority to sign. The hapless obligor must make up his own mind about all questions of this type: if he pays the assignee and the purported assignment turns out to have been invalid, he will still owe the money to his original creditor; if he pays the original creditor and the assignment turns out to have been valid, he will still owe the money to the assignee. Nor is it as clear as it should be that, in a situation where the validity of an assignment is in dispute, the obligor is entitled to pay the money into court and force the adverse claimants to interplead.

Obligors so situated have naturally attempted to protect themselves by writing into their contracts clauses purporting to prohibit assignments. Traditional doctrine has recognized the effectiveness of such anti-assignment clauses, but in fact there are almost no cases which, in a recognizably commercial context, hold that an obligor can resist an assignee's action on the strength of the clause alone. ${ }^{23}$ Arguably codifying what the courts have done,

22. For the "fragmentation" of security law, see Gilmore \& Axelrod, Challel Securily", 57 YALE L.J. 517, 761 (1948).

23. The traditional doctrine is accepted in Restatenfent, Contracts $\S 151$ (1932): "A right may be the subject of effective assignment unless ... (c) the assignment is pro- 
rather than what they have said, section 9-318(4) of the Code tersely provides that: "A term in any contract between an account debtor and an assignor which prohibits assignment of an account or contract right to which they arc parties is ineffective."

Harsh as assignment law has been against the obligor in forcing him to recognize assignments, it has cherished his interests tenderly in preserving his contract defenses against the assignee with whom he must deal whether he will or no. The conventional metaphor is that the assignee stands in the assignor's shoes. Unlike the holder in due course of a negotiable instrument, the assignee of a non-negotiable claim has no greater rights against the obligor than did the assignor. Like most unequivocal propositions of law, this one is hard at the core but softens as we approach the penumbra. We shall take as our texts section 167 (1) of the Restatement of Contracts ${ }^{24}$ and section $9-318(1)^{25}$ of the Code which, the official Comment assures us, "makes no substantial change in prior law."

The Restatement subjects the assignee to "limitations", "absolute and temporary defenses", "set-offs" and "counterclaims". The term "limitations" is obscure and is not clarified by anything in the Comment: conceivably it was put in merely for emphasis and adds nothing to the other terms. The reference to "temporary" as well as "absolute" defenses is also both obscure and unexplained. Presumably a "temporary" defense is one that would have been "available against the obligee" at the time of the assignment but thereafter, for some reason, has ceased to be "available". It is simply not clear whether

hibited by the contract creating the right." One of the few cases is Althusen $v$. Caristo Constr. Corp., 303 N.Y. 446, 103 N.E.2d 891 (1952); Sillman v. Twentieth Cent.-Fox Film Corp., 3 N.Y.2d 395, 144 N.E.2d 387 (1957), did not overrule Allhusen but signifi* cantly limited its scope. The Allhusen-Sillman sequence is very nearly duplicated in a pair of recent California cases: Benton v. Hofmann Plastering Co., 24 Cal. Rptr. 268 (Ct. App. 1962) ; St. Paul Fire \& Marine Ins. Co. v. Barnes Constr. Co., 26 Cal. Rptr. 646 (Ct. App. 1962), rev'd on other groutnds, 59 Cal. 2d 691 (1963). Both the New York and California sequences come to an end with the enactment of the Code, in the light of \& 9-318 (4), quoted in the next passage of the text.

24. Restatemsent, Contracts $\$ 167$ (1) (1962):

An assignee's right against the obligor is subject to all limitations of the obligco's right, to all absolute and temporary defenses thereto, and to all set-offs and counterclaims of the obligor which would have been available against the obligee had thero - been no assignment, provided that such defenses and set-offs are based on facts existing at the time of the assignment, or are based on facts arising thereafter prior to knowledge of the assignment by the obligor.

25. U.C.C. \& 9-318(1) :

Unless an account debtor has made an enforceable agreement not to assert defenses or claims arising out of a sale as provided in Section 9-206 the rights of an assignce are subject to

(a) all the terms of the contract between the account debtor and assignor and any defense or claim arising therefrom; and

- (b) any other defense or claim of the account debtor against the assignor which accrues before the account debtor receives notification of the assignment. 
the restaters meant that the "temporary defense", after it has so to say lapsed, continues nevertheless to be available against the assignee (who originally took subject to it) or that the defense, if it lapses against the "obligee", also ceases to be available against the assignee. The present author is not familiar with any case law on which the restaters may have been relying. The use of the terms "set-offs" and "counterclaims", as distinguished from "defenses", makes clear that the obligor may assert against-the assignee not only defenses arising out of the contract which was the subject matter of the assignment but also claims of any sort, which may have arisen out of past transactions or be totally unrelated to the contractual nexus.

Section 9-318(1) subjects the assignee to "defenses" and "claims". "Claims" no doubt include the Restatement's "set-offs" and "counterclaims". The Code does not reproduce either the curious distinction between "absolute" and "temporary" defenses or the obscure suggestion that there may be "limitations" on the assignee's right which are less than, or different from, "defenses" or "claims". The Code adds a phrase (and perhaps a thought) which is not found in the Restatement: the Code assignee is subject not only to "defenses" and "claims" but to the "terms" of the underlying contract. ${ }^{20}$ The Code states explicitly the point which we concluded was already clear enough under the Restatement: the account debtor (obligor) can assert both his contract defenses and "any other defense or claim". which he may have against the assignor.

Both Code and Restatement assume that the situation changes radically at the point when the assignee gives notification of the assignment. The two formulations, however, are somewhat different. According to the Restatement the obligor's defenses and set-offs (as well as, presumably, his counterclaims) are available against the assignee only if they are "based on facts existing at the time of the assignment, or . . . arising prior to knowledge of the assignment by the obligor." This language might be helpful to anyone who knows how to tell exactly when "facts" "exist" or "arise"; to anyone else the language is meaningless except as a general statement that there must be some otherwise available "defenses and set-offs" which are not available against a notifying assignee. The Code improves on the Restatement by the device of distinguishing between what might be called the contract-related and the unrelated defenses and claims. Defenses and claims "arising"-from the contract can be asserted against the assignee whether they "arise" before or after notification. As we shall see, that is presumably what the restaters meant: the contingencies of future performance of the contract were to be regarded as "facts existing at the time of the assignment." Under the Code, "any other defense or claim"

26. For example, assume that a sales contract includes a flexible or open price term: the price of goods sold is to be set periodically by seller, or conceivably by buyer, or by the two acting together, or by a third party or in accordance with specified price indices. (On open price terms under the Code, see $\$ 2-305$.) This is a "term" of the contract to which, under \&9-318(1), the assignee's rights are "subject". There may be an implication that, if the term provided for the seller-assignor to set the price, that right would not pass to the assignee but would still be exercised by the seller. 
is available against the assignee only if it "accrues before ... notification." It may be admitted that it is no easier to tell when a "claim" "accrues" than it is to tell when a "fact" "arises". However, without further pursuing the problem of the unrelated claims, we shall restrict ourselves to the contractrelated defenses.

\section{The defense of breach of warranty}

Let us assume that A sells B his horse, Bucephalus, warranting Bucephalus to be sound, and assigns to $C$ his claim for the price; or that $A$ contracts for a stated price to repair B's roof so that it will not leak and likewise assigns that claim to C. If it now appears that Bucephalus was not sound or that, after $A$ has completed his repairs, the roof still leaks, can $C$ nevertheless collect the price from $B$ ?

No one has ever doubted that $C$ takes subject to defenses of this type, both under the sales contract and the service contract. Nor would it make any difference whatever whether $\mathrm{C}$ had notified $\mathrm{B}$ of the assignment before $\mathrm{A}$ had delivered Bucephalus or started to repair the roof. For so elementary a propon sition it would be pointless to cite authority: it is so because it is so. Under section 9-318(1) of the Code, both defenses "arise from" the contract (or its terms) and are thus available against the assignee. Under Restatement section 167 , the unsoundness of Bucephalus at the time of the sale would clearly enough be a "fact existing" at the time of the assignment. That A's prospective failure to repair the roof properly is also a "fact existing . . . or . . . arising" before notification may seem an odd use of words but the illustration shows clearly that that was what was meant. 27

Between buyer and seller the unsoundness of Bucephalus or the leaking of the roof would be available both as defenses and as claims. If seller sued for the price, buyer would plead breach of warranty or failure of consideration as a defense. But buyer could also sue seller (or bring a counterclain in the seller's action) to recover a down payment or any damages that may have resulted from the breach. Between buyer and seller's assignee, however, the breach of warranty or failure of consideration is available only defensively: if buyer wishes to recover his down payment or his damages, he must go directly against his seller. The assignee, wha comes in to finance the transaction, does not thereby become responsible for the assignor's warranties or prospective performance. $^{28}$

27. Restatement, Contracts \& $167(1)$, illustration 3 (1962) puts the following hypothetical case as an illustration:

A has a bilateral contract with $B$, in which the promises are dependent. $A$ assignts his rights thereunder to $C$, who informs $B$ of the assignment. Thereafter, $A$ wholly fails to perform his own duties under the bilateral contract. $C$ has no right against B.

28. The only cases which seem ever to have questioned this proposition arose from a misreading of the warranty provisions of the UNIFORM Biles of LAdina ACr: an occasional court, between 1910 and 1920, held that a financing bank which indorsed and delivered a bill of lading thereby warranted the quality of the goods. See Note, 26 Colum. 
The only problem that has ever caused any trouble in this area is whether buyer can effectively agree that he will not assert against assignee defenses which would be available to him against seller. In a sense the obligor's agreement to waive his defenses is the reverse of the attempt by the obligor to prohibit assignments of claims against him. Here too the courts have shown themselves somewhat disinclined to allow the stronger of the contracting parties to write his own ticket.

Our legal system has, of course, long provided a system under which a financing agency can hold free of contract defenses. That is, it might be said, what the law of negotiable instruments is all about. If the bank or finance company which advances to a seller the purchase price of goods sold becomes the holder in due course of the buyer's note or acceptance, then it can enforce the note or acceptance free of the buyer's contract or personal defenses against the seller. It may be observed that the financing agency's defense-free position depends on the buyer's consent or agreement: if he refuses to execute the note or accept the seller's draft, there will be nothing that the lender can hold in due course.

With the rise of consumer finance half a century or more ago, the pioneering sales finance companies began experimenting with contractual clauses designed to have the same effect as negotiable notes. It may be that some buyers objected to executing negotiable notes or that it was simply more convenient to have the instalment buyer execute one piece of paper (typically, a conditional sale contract) than two pieces of paper (a conditional sale contract plus a negotiable note). Waiver of defense or, as they came to be called, cut-off clauses began appearing in the case reports about 1910 and have been with us ever since. When finance companies, as assignees of contracts containing such clauses, attempted to collect the full price from buyers who had been sold worthless goods, the judicial reaction was uncertain and confused. After 19.10, however, the case law trend seemed to be against the validity of the clauses and in a number of states this trend was reinforced by statutes, known as Retail Instalment Sales Acts, which altogether prohibited the use of cut-off clauses. ${ }^{29}$

L. Rev. 63 (1926), and a communication on the same subject from Professor Williston (the draftsman of UBLA), 26 CoLuMr. L. Rev. 330 (1926). The Code insures that the same confusion cannot occur in documentary transactions: under $\$ 7-508$ a financing agency" in such a transaction warrants only "its own good faith and authority." And § 9-317 provides that: "The mere existence of a security interest or authority given to the debtor to dispose of or use collateral does not impose contract or tort liability upon the secured party for the debtor's acts or omissions."

29. The contract litigation, indeed, had a backlash effect on the negotiable instrument cases. Courts which had decided that the finance companies (and the banks, which began to play a role in consumer finance after World War II) should be denied their deiensefree position as contract assignees were not long in coming to the conclusion that they should also be denied that position as holders of negotiable paper. The usual judicial method of arriving at that result was to hold that a finance company (or bank) which regularly financed a dealer was too intimately involved in the total transaction to be con- 
The question of the consumer-buyer and his defenses led to violent controversy in the drafting of Article 9 of the Code. In the early stages of drafting, a comprehensive treatment of the problems of consumer finance had been contemplated. This plan was eventually abandoned and it was decided that the protection of consumers would be left to the courts or to Retail Instalment Sales Acts. However, fragments of the earlier approach survived through successive drafts, and it was not until 1956 that a provision was deleted which was designed to preserve the consumer-buyer's defenses both in contract cases and negotiable note cases.

In the final draft of the Code, the provisions of section 9-318(1) on the availability of defenses against assignees are, by the preamble, made subject to any "enforceable agreement not to assert defenses or claims arising out of a sale as provided in section 9-206." Section 9-206(1) takes the problem of who may make such "enforceable agreements" in two bites. First, it leaves the matter of consumers to other law, statutory or decisional; second, it provides affirmatively that, except for consumer transactions, defenses may be waived either by contract or by signing a negotiable instrument. ${ }^{80}$

There is a certain amount of slippage in the drafting as we go from section 9-318(1) to section 9-206(1). Section 9-318(1) talks of "account debtors" who make "enforceable agreements not to assert defenses or claims arising out of a sale." If it were not for the restrictive phrase "arising out of a sale," the reference would be to any type of obligor who owes, or may in the future owe, any type of contractual obligation not evidenced by a negotiable instrument: "account debtor" is defined (section 9-105) as "the person who is obligated on an account, chattel paper, contract right or general intangible."81 However, if we take the section 9-318(1) cross-reference to section 9-206 literally, we are told that the section 9-206 rules on "enforceable agreements"

sidered a holder in due course. Once again, in some states, the Retail Instalment Sales Acts prohibited the use of negotiable notes in consumer sales transactions. Sce Gilmore, The Commercial Doctrine of Good Faith Purchase, 63 YALE L.J. 1057, 1093-1102 (1954); Hogan, A Survey of State Retail Instalment Sales Legislation, 44 ConNelL L.Q. 38 (1958).

30. U.C.C. $\$ 9-206(1)$ provides:

Subject to any statute or decision which establishes a different rule for buycrs or lessees of consumer goods, an agreement by a buyer or lessee that he will not assert against an assignee any claim or defense which he may have against the seller or lessor is enforceable by an assignee who takes his assignment for valuc, in good faith and without notice of a claim or defense, except as to defenses of a type which may be asserted against a holder in due course of a negotiable instrument under the Article on Commercial Paper (Article 3). A buyer who as part of one transaction signs both a negotiable instrument and a security agreement makes stch an agreement.

31. For the definitions of "account", "contract right" and "general intangible", see the text at note 68 infra. Under the Article 9 classification of property, these are the three classes of "pure" intangibles - i.e. claims not represented by an instrument, negotiable or non-negotiable, or by "chattel paper". For the definitions of "instrument" and "chattel paper", see U.C.C. \$§ 9-105(b) and (g). 
will prevail over the section 9-318(1) rules on the availability of defenses only with respect to "account debtors" who are buyers of goods. On the other hand, section 9-206 itself covers not only "buyers" but "lessees", so that it is somewhat broader than the restrictive cross-reference, though it is still far from covering all types of contracts.

The slippage must be put down to a failure to coordinate two sections which, in their origins, were directed to unrelated problems. There appears to be no reason whatever why a businessman, as distinguished from a consumer, should not have the capacity to waive his present or prospective defenses in favor of a financing assignee. It is clear enough that he can do this by executing a note or accepting a draft; there is no reason why he should not be able to do it by a contractual waiver. When the original purpose of section 9-206 (the protection of consumers) was abandoned, the rule that, except in consumer transactions, contractual waivers are effective should have been generalized so that it applied not only to "buyers" and "lessees" but to all "account debtors" and, so generalized, made a part of section 9-318. The present wording of the section 9-318(1) cross-reference can unfortunately be read to mean that only "account debtors" who are buyers of goods can ever waive their contract defenses. The purpose of this tedious discussion is to suggest that such a senseless restriction was never intended and that the careless wording of the cross-reference, to the extent that it suggests such a restriction, should be disregarded. Furthermore, the affirmative provisions of section 9-206, which validate contractual waivers except in the area of consumer transactions, should be taken to apply, directly or by analogy, to all account debtors. The section is written in terms of present sales (and leases) of goods; however, if the language is read in a cheerful spirit, there is no insuperable difficulty in applying it to transactions which are not sales and leases and to executory as well as executed obligations.

\section{The defense of non-performance or total failure of consideration}

Doctrinally, the case of failure of performance is merely a fortiori the case of attempted but defective performance. Factually, the two cases may raise somewhat different issues.

One of the few cases in which it has ever been argued to a court that an assignee can recover from an obligor despite non-performance by the assignor is Sponge Divers Association, Inc. v. Smith, Kline \& French Co. ${ }^{32}$ The Sponge Divers had a contract to sell sponges to Smith, Kline \& French and has assigned the "book account" to Commercial Credit. At least some sponges were shipped under the contract; a "statement of account", which accompanied the bill of lading, "had stamped upon it plain notice that the ownership of the account and also the title to the goods shipped were in the credit company." Smith, Kline \& French, having inspected the sponges, rejected them on the ground that they were not up to contract specifications and returned them to

32. 257 Fed. 328 (E.D. Pa. 1919), aff'd, 263 Fed. 70 (3d Cir. 1920). 
the Sponge Divers. No other sponges were ever shipped. Commercial Credit then sued Smith, Kline \& French for the purchase price of the sponges which had been shipped and rejected. There was a jury verdict for Smith, Kline \& French, motion for a new trial was denied and an appeal was taken to the Third Circuit.

From the opinion of the district court, ruling on the motion for a new trial, it is apparent that the principal issues which had been raised at the trial had been whether Smith, Kline \& French had inspected and rejected the sponges within a reasonable time and whether it had acted properly in sending the goods back to the Sponge Divers instead of sending them to Commercial Credit, of whose interest it clearly had notice. The district court ruled that the first issue had been properly stubmitted to the jury and that, apparently, Commercial Credit was estopped to raise the second issue (which was therefore not decided on the merits). Neither of these rulings was disturbed on appeal.

The issue to which Judge Buffington's opinion for the Third Circuit was devoted was the trial court's refusal to charge the jury that:

Where there has been an absolute assignment in good faith and for a valuable consideration of the whole interest of the assignor in a chose in action, the assignor's control over it ceases immediately after the assignment and notice, and he can do nothing thereafter to prejudice or defeat the rights of the assignee. ${ }^{33}$

The source of the requested instruction, which is not identified in Judge Buffington's opinion, was the article on Assignment in Corpus Juris. . $^{34}$ The point should be made, however, that none of the many cases which the learned author of the Corpus Juris article cites, had anything to do with the proposition which counsel for Commercial Credit were so oddly arguing: that, following assignment and notice, Smith, Kline \& French had to pay Commercial Credit whether the Sponge Divers performed the contract or not - as if Smith, Kline \& French had executed a negotiable note which had been negotiated in due course to Commercial Credit. Naturally, the argument got nowhere. Judge Buffington put the affirmance of the decision below on the ground that until the sponges had been delivered and accepted, there was no "account" in existence which could be assigned to Commercial Credit. It might better have been put on the ground that whatever rights Commercial Credit acquired by the assign * ment were subject to the proper performance of the contract by the Sponge Divers, but the result cannot be quarreled with.

Few assignees of executory contracts have ever even argued the point, and it may be doubted whether Commercial Credit would have sued Smith, Kline \& French if there had not been so many other issues involved in the case. Certainly no bank which has ever made a construction loan has attempted to recover from the owner when the contractor has abandoned the contract without

33. 263 Fed. at 71.

34. 5 C.J. 959. On the Corpus Jurrs article, see further text at note 51 infra. 
even beginning performance. The Sponge Divers case was of course not one of total nonperformance but of attempted performance which was rightiully rejected: from the point of view of the assignee's risk, the two situations may be taken as identical. ${ }^{35}$

A minor point, which is somewhat discussed in the district court's opinion in the Sponge Divers case, is whether the buyer, when he rejects tendered goods after he has been notified of an assignment, should deal with the seller or the assignee. Quite apart from the additional complexities introduced by the assignment, sales law has never been clear about what the duties of a buyer are with respect to rightfully rejected goods. May he let them rot on the siding? Must he take care of them? Must he ship them back to the seller? At whose expense? With respect to such questions, section 69 of the Uniform Sales Act was an impenetrable maze. The Sales Article of the Code is a great improvement. In the first place, the buyer must "seasonably" notify the seller of his rejection; if he does not, the rejection is "ineffective" [section 2-602(1)]. Secondly a buyer who has "before rejection taken physical possession of goods ... is under a duty after rejection to hold them with reasonable care at the seller's disposition for a time sufficient to permit the seller to remove them" [section 2-602(2) (b)]. Unless the buyer is a merchant, he has no further duties. If he is a merchant, he is put, under certain circumstances, under the duty of following the seller's "reasonable instructions", subject to a right to demand indemnity for his expenses [section 2-603(1)].

The Code is, however, no clearer than pre-Code law on whether, after notification of assignment, the rejecting buyer should deal with his seller or the assignee. Which should he notify? Whose instructions should he follow? There is a section of the Sales Article (section 2-506) which provides that a "financ-

35. In Firestone Tire \& Rubber Co. v. Central Nat'l Bank, 159 Ohio St. 423, 112 N.E.2d 636 (1953), a seller assigned to the bank purported accounts which were in fact fictitious: no goods had been shipped and the bills of lading which accompanied the invoices had been forged. It was the buyer's (Firestone's) practice to pay on receipt of invoice without waiting for arrival of the goods. Before notification of the assignment, it paid one of the assigned invoices by issuing its check to the seller, who endorsed it to the bank which credited the amount against its loan. After notification, it paid the other invoices by issuing its checks to the bank which applied some of the proceeds in reduction of the loan and made the balance available to the seller. On discovery of the fraud several months later, Firestone sued the bank to recover the amounts paid. Held, that Firestone could recover with respect to the checks issued to the bank to the extent that the banks had credited the proceeds against the loan. With respect to the balance, which the bank: had paid over to the seller (against whom bankruptcy proceedings had been instituted), the Court felt that the bank had so changed its position that a judgment for Firestone would be inequitable. With respect to the check issued to the seller and indorsed to the bank, the Court concluded that the bank had become a holder in due course so that it held free of Firestone's claim. The Court may have been unduly impressed with the negotiable instruments aspect of the case. The principal holding in the case, however, is that, where the assignor fails to perform the contract, the assignee cannot retain mistaken, or even negligent, payments made to it by the obligor unless there has been a subsequent change of position by the assignee. 
ing agency" which for value acquires "a draft which relates to a shipment of goods" gets, among other things, "any rights of the shipper in the goods"; this would seem to include the right to be notified and to give instructions in the event of rejection. Another provision of the Sales Article (section 2-707) is that "a person in the position of a seller" may exercise certain remedies of the seller, such as stoppage in transit. This section says nothing about rejection by the buyer and it is not entirely clear who is "a person in the position of the seller": an obscure definition [section 2-707(1)] describes him as someone who, as agent or principal, has "paid or become responsible for the price of goods". There is no reason to believe that either section 2-507 or section 2.707 applies to an assignee who has not purchased a mercantile draft. Nor is there anything directly relevant in Article 9 of the Code. Section 9-306(4) deals with priorities between an inventory financer and a receivables financer in the situation where the goods whose sale created the receivables "are returned to or repossessed by the seller or the secured party" [who is the assignee of the receivable]. That priority provision sheds no light whatever on whether a buyer who is entitled to return goods and rescind the sale should return them to the seller or the assignee.

In view of the obscurity of the Code, to say nothing of the pre-Code law, a rejecting buyer who has been notified of an assignment would be prudent to notify both seller and assignee. If he then received conflicting instructions about what to do with the goods he would, unfortunately, be on his own and would have the chance to make some new law. As a matter of policy, it seems reasonable to conclude that, despite notification of assignment, the buyer should in the typical situation be privileged to go on dealing with the seller alone: the assignee's involvement is with the financing aspect, not the goods aspect, of the transaction. This policy conclusion will be buttressed with a certain amount of legal support when we take up the question of the extent to which the two contracting parties remain free, despite assignment and notification, to modify, or indeed rescind, the contract without the assignee's consent. ${ }^{38}$

The defense of discharge by change of circumstance (herein of the doctrine of frustration)

It follows from what we have already said that whatever discharges the obligor or gives him a defense against the other contracting party also disu charges him or gives him a defense against an assignee who is merely an assignee and not, for example, the due course holder of the obligor's negotiable paper. From the point of view of the assignee of the proceeds of an executory contract, it thus becomes extremely relevant to consider to what extent reasons other than the assignor's non-performance or defective performance will discharge the obligor from his contractual duty to pay. The longer the term of the contract, the more relevant the question becomes. In the context of our present discussion, the major event, other than breach by the other party,

36. See text at notes 50-82 infra. 
which may discharge the obligor is a change of circumstances of so fundamental a nature that, to use current terminology, the obligor's purpose in entering into the venture has been frustrated.

It is sometimes said that there was a time when the general rule of the common law was that no difficulty of performance, however great, discharged a promisor from his contractual duty. If, in fact, he could not do what he had promised to do, he could, as an alternative, pay damages - but no adverse change of circumstances, however catastrophic, would relieve him from the consequences of a promissory obligation voluntarily entered into. ${ }^{37}$ Proponents of this view go on to say that the old, harsh rule has gradually softened or, perhaps, given way to a more humanitarian approach: not merely absolute impossibility of performance but extreme difficulty of performance or what might be called economic impossibility will now discharge a promisor. ${ }^{33}$ The term "frustration" is sometimes used as a loose synonym for the sort of impossibility, physical, legal or economic, that has come to be considered as an event of discharge.

It is suggested that "harshness" and "humanitarianism" have nothing to do with the matter. For every $A$ who is a promisor, there is necessarily a $B$ who is a promisee. A rule which keeps A nailed to his contractual cross, despite unanticipated catastrophe for which he is in no sense at fault, is admittedly harsh on $A$. On the other hand a rule which lets $A$ go free will be equally harsh on $B$ who, by hypothesis, is no more responsible than $A$ for what has happened. The equities of the situation become particularly difficult to balance when, before the catastrophic event has occurred, A or B, or both, in performance of, or in reliance on, the contract, have incurred expenses which will represent a dead loss in the event the contract cannot be carried out. ${ }^{30}$

37. A passage dear to the heart of editors of all contract case books is the following, from the opinion of Young, J., in Stees v. Leonard, 20 Minn. 494, 503-04 (1874):

The general principle of law which underlies this case, is well established. If a man bind himself, by a positive, express contract, to do an act in itself possible, he must perform his engagement, unless prevented by the act of God, the law, or the other party to the contract. No hardship, no unforeseen hindrance, no difficulty short of absolute impossibility, will excuse him from doing what he has expressly agreed to do. This doctrine may sometimes seem to bear heavily upon contractors; but, in such cases, the hardship is attributable, not to the law, but to the contractor himself, who has improvidently assumed an absolute, when he might have undertaken only a qualified liability. The law does no more than enforce the contract as the parties themselves have made it.

Not all the editors are careful to point out that the plaintiff in Stees v. Leonard was suing principally to recover a down payment made to the defendant before the job had been abandoned; he was not suing to recover normal contract damages. Sce the editors' statement of facts for Stees v. Leonard in Fuller \& Braucher, Bastc Contract LAw 559 (1964).

38. Linz v. Schuck, 106 Md. 220, 67 Atl. 286, 11 L.R.A. 789 (1907), is often cited as a leading case in support of this proposition.

39. These complex problems are admirably discussed in Comment, Apportioning Loss After Discharge of a Burdensome Contract: A Statutory Solution, 69 Y ALE L.J. 1054 (1960). The author proposes a draft statute which is of great interest. 
In most contractual situations one party is under a duty to manufacture or to build or to transfer property or to render services while the other party is under a duty to pay money in exchange for the other party's performance: we shall speak of the performing party and the paying party. It is suggested that the common law rule has always been that impossibility of performance discharges the performing party and dissolves the contract: two illustrations of the rule are that incapacity or death discharges a contract to perform personal services (that is, neither the party who has contracted to serve nor his estate is liable in damages for the non-performance) ${ }^{40}$ and that destruction of goods contracted to be sold, before the property in the goods has passed to the buyer, discharges the seller. ${ }^{41}$ On the other hand, the general rule seems to have been that the paying party is never discharged merely because the performance he has promised to pay for has become, because of an unanticipated turn of events, useless, or even burdensome, to him. Since the performing party's discharge was put on the ground of "impossibility", the rule of no discharge for the paying party was sometimes sought to be explained by the observation that "it is never impossible to pay money." 42

It is further suggested that the so-called "frustration" cases which begin to appear in the English reports toward the end of the nineteenth century represented an extension of the rule of discharge by reason of changed circumstances from performing parties to paying parties. ${ }^{43}$ Once that extension had been accomplished, it operated by a sort of backlash to expand the range of events which would discharge performing parties. Since "impossibility of performance" was no longer the key to the developing rule of discharge, performance, like payment, would evidently have to be excused by something less than absolute impossibility.

Such an explanation poses at least as many questions as it provides answers. Why should performance have been excused under circumstances which, reversed, would not have excused payment? Why, in this century, should there have been a disposition to apply the same rule of discharge on both sides of the contractual equation, with the result of broadening the range of events which lead to a discharge on either side? We shall not further pursue these essentially jurisprudential inquiries. At all events, as a matter of descriptive statement, all shades of opinion seem to be in agreement that, just as the gradual erosion of the nineteenth century doctrine of consideration makes it easier to impose contractual obligation in the first place, so the gradtual broad-

40. See generally 6 Corbin, Contracrs $\$ 1334$ et seq. (1962).

41. Id. at $\$ 1337$; UNIFORM SAIES ACT $\$ \S 7,8$; U.C.C. $\$ 2-613$.

42. At least in contemplation of law. It may of course be impossible in fact to pay money on a given day - for example, because all the banks in the country have been closed - but that should make no difference. See, e.g., Levy Plumbing Co. v. Standard Sanitary Mfg. Co., 68 S.W.2d 273 (Tex. Civ. App. 1934).

43. See the opinion of Blackburn, J., in Taylor v. Caldwell, 3 Best \& S. 826, 122 Eng. Rep. 310 (1863); see also Krell v. Henry, L.R. 2 K.B. 740 (1903), one of the so-called Coronation cases. 
ening of the rules of discharge or excuse makes it easier for the contracting parties to escape from obligations voluntarily assumed.44

A hypothetical case will serve to illustrate the changing state of law. Assume a contract between a seller who is a manufacturer of components or subassemblies and a buyer who is a manufacturer of a completed product $-a$ common situation in, for example, the automobile industry. It is understood by seller and buyer that the components are to be manufactured in the seller's factory (and nowhere else) and are intended for use in the buyer's factory (and nowhere else). Suppose in one instance the seller is unable to manufacture the components because of circumstances beyond his control: strike, fire or what is referred to as force majeure or, oddly, as the act of God. Suppose, alternatively, the buyer is unable to use the components in his manufacturing operation, since his factory has been shut down because of circumstances of the same sort; which are equally beyond his control. The common law and the codifying statutes have always been clear that, on the facts hypothesized, the seller was discharged - without regard to the presence or absence of a socalled force majeure or "strike and fire" clause in the contract. ${ }^{45}$ This was a clear case of objective or absolute impossibility. In the reverse situation, however, unless the contract contained a force majeure clause which operated to relieve the buyer, the common law position was that the buyer was not discharged. The use which he might make of the components had nothing to do with the contract, which merely required the seller to deliver and the buyer to pay. Thus he must pay, even though he no longer has any use for the components - even though his original purpose in entering into the contract has been completely frustrated.

In the Restatement of Contracts, the doctrines of "impossibility" and "frustration" are not even on speaking terms with each other. Chapter 14 of the Restatement (sections 454-469) deals with "impossibility". A distinction is taken (section 455) between "subjective" and "objective" impossibility; only "objective" impossibility discharges a promisor from his duty. If our hypothetical case is analyzed in terms of Chapter 14 of the Restatement, it is clear

44. But see Berman, Exciuse for Nonperformance in the Light of Coniract Practices in International Trade, 63 CoLuM. L. Rev. 1413 (1963). Professor Berman analyzes the litigation which arose from the closing of the Suez Canal in 1956. While he agrees thast the trend in contract law during this century has been in the direction of increasingly liberal rules of discharge, he feels that this has been a bad trend ("an unwarranted liberalization of excuse") which should be reversed ("The solution ... lies in the opposite direction."). Id. at 1439.

45. We have assumed that it was a clearly understood term of the contract that the components were to be manufactured in the seller's factory (and nowhere else). The case is altered - and the seller is not discharged - if his contract is construed as a "general contract", without any particular source for the goods being specified. In such a case, cren if his expected source of supply fails, he is under a duty to go into the market to procure the goods. The principal function of a "strike and fire" clause is to make clear that, in the terms of our hypothetical illustration, the seller's factory was the one and only source from which the goods were to come. 
enough that the seller is discharged but that, in the reverse situation, the buyer is not - the pre-Restatement common-law position. On the other hand, in the course of Chapter 10 on "conditions", the Restatement puts forward an exceedingly broad rule of "frustration" (section 288) :

Where the assumed possibility of a desired object or effect to be attained by either party to a contract forms the basis on which both parties enter into it, and this object or effect is or surely will be frustrated, a promisor who is without fault in causing the frustration, and who is harmed thereby, is discharged from the duty of performing his promise unless a contrary intention appears.

One of the illustrations to section 288 concerns the frustration of maritime charter parties - a subject which had been much litigated during World War $\mathrm{I}^{46}$ - and provides that if, because of a wartime shipping embargo, the charterer cannot use the vessel, he is thereby discharged from the dity to pay the charter hire. Our hypothetical buyer, who cannot use the components, might seem to be, economically and morally, in the same situation as the charterer who cannot use the vessel. It seems fair to say that the Restatement points ambiguously in both directions - which may have been the most sensible thing for the restaters to have done in a situation where the underlying state of law was itself ambiguous and, arguably, in flux or transition.

During the Great Depression of the 1930's a considerable amount of litigation arose over long-term requirements contracts. Such contracts seem to have come into use - at all events they begin to appear in the case reports - enrly in this century. The great question which such contracts seemed, initially, to present to the courts was whether they were contracts at all : was the buyer's promise to buy his future "requirements" sufficient consideration to support the seller's promise to supply them, or was the whole arrangement "illusory"? By the time the Depression came along, that question had been answered : the arrangement was not illusory, there was sufficient consideration, there was a contract which bound both parties. ${ }^{47}$

The Depression cases analyzed requirements contracts in the situation where the buyer's requirements fell to zero: either he decided voluntarily to go out of an unprofitable business or he was involuntarily forced out of business into bankruptcy. In either case, did the buyer (or his trustee in bankruptcy) hate to pay damages to the disappointed seller? The problem was compounded when it appeared that the seller had - say, in 1929 - put up a new factory, or expanded his old factory, for the express purpose of supplying the buyer's anticipated requirements over the next ten years. With remarkable unanimity, the courts decided, both in the bankruptcy and in the non-bankruptcy cases, that the sellers could not recover damages: apart from express agreement they might not recover even for expenses incurred in relinnce on the continu-

46. See Gilasore \& Brack, The Law of Admiralty § 4-19 (1957).

47. For the cases and discussion, see $1 \mathrm{~A}$ CoRmin, Contracts $\S 156 \mathrm{ct}$. scq. (1963). 
ance of the buyer's business during the term of the contract. ${ }^{48}$ These cases were not analyzed in terms of section 288 of the Restatement of Contracts or of the doctrine of frustration - which was sometimes said to be an English invention, not favored in this country. ${ }^{40}$ The courts chose, instead, to write their opinions as exercises in interpretation of language: when the buyer promised to buy his "requirements", he meant only such requirements as "in good faith" he might have, so that if, "in good faith" he decided to go out of business and have none, he had not breached his contractual duty. From this point of view, the case of the buyer who had been forced into bankruptcy was even clearer than the case of the buyer who had the good sense to quit while he was still ahead. It may be questioned whether a seller who was left to cope as best he could with a large unamortized investment in new plant felt that his own contractual intent had been accurately interpreted. But the "going out of business" cases were surely not the first in which a rule of substantive law has been put forward under the pretense that the courts were merely carrying out the intention of the parties.

Until the enactment of the Code, the matters we have been discussing were, in this country, almost entirely within the domain of the uncodified general law of contracts. The Code, at least with respect to contracts for the sale of goods, provides a statutory base.

The Sales Article of the Code, after restating (section 2-613) the traditional rules which discharge a seller when goods contracted to be sold are accidentally destroyed before their risk has passed to the buyer, adds a provision which has no statutory predecessor and which might be described as a codification of the common law doctrine of frustration. Section 2-615, captioned "Excuse by Failure of Presupposed Conditions", provides that a seller's delay in delivery or non-delivery

is not a breach of his duty under a contract of sale if performance as agreed has been made impracticable by the occurrence of a contingency the non-occurrence of which was a basic assumption on which the contract was made. . . .

The seller's excuse under section 2-615 is conditioned on his compliance with provisions which require him to carry out his existing contracts to the extent it may be possible for him to do so by allocating among his customers whatever he can still produce and deliver.

48. Illustrative cases are In re United Cigar Stores Co., 8 F. Supp. 243 (S.D.N.Y. 1934) (bankruptcy), and Fort Wayne Corrugated Paper Co. v. Anchor Hocking Glass Corp., 130 F.2d 471 (3d Cir. 1942) (non-bankruptcy). In the Fort Wayne case, the seller had put up money for the enlargement of the factory and terms had been agreed upon for the amortization of the advance. At trial the seller recovered judgment for the portion of the advance which had not been amortized when the buyer decided to go out of business; no appeal was taken from that judgment, which is therefore not considered in the court's opinion. Cf. Babson ₹. Village of Ulysses, 155 Neb. 492, 52 N.W.2d 320 (1952), discussed in the text following note 59 infra.

49. See the opinion of Traynor, J., in Lloyd v. Murphy, 25 Cal. 2d 48, 153 P.2d 47 (1944). 
From our point of view, the most interesting thing about section 2-615 is that, no doubt reflecting the common law background but unlike Restatement section 288, it states a one-way frustration rule, applicable, so far as the express language of the section goes, to sellers but not to buyers. The case of the buyer is, however, discussed at considerable length in the accompanying Comment.

The reader of the Comment is told, in the first instance, that, "Exemption of the buyer in the case of a 'requirements' contract is covered by the 'Output and Requirements' section both as to assumption and allocation of the relevant risks." That section (section 2-306) proposes what is essentially a rule of interpretation. A promise by a buyer to buy his requirements means "such actual ... requirements as may occur in good faith ...." The Comment to section 2-306 remarks somewhat ambiguously: "A shut-down by a requirements buyer for lack of orders might be permissible when a shut-down merely to curtail losses would not. The essential test is whether the party is acting in good faith." The evident intention of the draftsmen of both the text of section 2-306 and the Comment was to codify the "going out of business" cases of the 1930's, both in treating the problem as one of interpretation of a contract term and in providing an interpretation which allows the buyer to cease having requirements, provided he does so "in good faith".

The balance of the section 2-615 Comment on the applicability of the frustration rule to buyers faces resolutely in both directions. It is first suggested at some length - indeed the point is repeated in successive sentences - that "commercial understanding" does not regard a buyer's contracts as conditioned on the continuing operation of his own plant or on the "continuance" of his contracts for resale. Then, with a sudden shift of ground, the Comment concludes:

On the other hand, where the buyer's contract is in reasonable commercial understanding conditioned on a definite and specific venture or assumption ... the reason of the present section may well apply and entitle the buyer to exemption.

The conclusion of the Code draftsmen was that the doctrine of excuse by frustration had won general acceptance with respect to.sellers, so that it was not enough to formulate the rules of seller's discharge in terms of "impossibility" alone. With respect to buyer's discharge, the draftsmen evidently felt that the best solution, against the background of a developing but unclear state of law, was to leave the matter unsettled but, so to say, "open-ended". If, as the Comment puts it, "commercial understanding" comes to be that buyers, like sellers, are "entitled to exemption", then there is no reason why section 2-615 should not be turned around and read from the opposite end.

A partial codification of a general rule always leaves a good many problems in its wake. With careful ambiguity, section 2-615 states a frustration rule applicable to sellers of goods. Nothing in the Code purports to cover the question of discharge of promisors in contracts other than those for the sale 
of goods. No doubt courts, sympathetic to the policy of section 2-615, might be inclined to apply it as a rule of general contract law or might look at section 2-615 as merely a special instance of the general rule supported by the authority of Restatement section 288. But it must be concluded that neither the Code nor the Restatement is of much help in either setting or mapping the limits of the gradually expanding rules of discharge from contractual duty by reason of changed circumstances.

From the point of view of an assignee whose security consists of the proceeds of long-term executory contracts, so soft or swampy a state of law is obviously regrettable. But there is no reason to believe that an area of law which has for so long been in confusion will in the predictable future develop any clarity of substance or precision of outline. And the long-term trend has unquestionably been adverse to the interests of assignees who make loans on such doubtful security.

\section{Freedom of the Contracting Parties to Modify or Rescind Without the AssigneE's Consent (The Pre-Code Law)}

\section{The Common Law}

The novelty of our subject matter is best illustrated by the fact that the extraordinarily rich literature of the law of contracts contains almost no reference to the problem stated in this subtitle. It may be that the instinctive reaction of the legal mind will be that there is no discussion because there is no problem: it is "obvious" that, at least after notification, the original parties can do nothing to prejudice the assignee's rights. Like most obvious propositions of law, this one becomes less obvious the further it is pursued into the jungle.

Many statements, both in judicial opinion and in learned commentary, which seem to support the proposition have been delivered in contexts that have nothing to do with the rights of assignee against obligor. Frequently the context turns out to be the problem of priorities between successive assignees of the same chose in action. In a state like New York, where the common-law rule was that the assignment first in time prevailed, one way of explaining the rule was to point out that, after the first assignment, the assignor no longer had any control over or interest in the chose. ${ }^{50}$ But whether the assignor could defeat his assignee by making a second, necessarily fraudulent, assignment is, obviously, at a far remove from whether he can defeat the assignee by making a good faith adjustment with the other party to the contract.

The anonymous author of the article on assignment in Corpus Juris seems to have been the first commentator to have discerned that there was a problem

50. Superior Brassiere Co., Inc. v. Zimetbaum, 214 App. Div. 525, 212 N.Y. Supp. 473 (1925), was a case of this type. It is not surprising that when such a proposition is put forward in a priority context, it is thereafter carried over in actions between assignce and obligor; see, e.g., Madison Industrial Corp. v. Elisberg, 152 Misc. 167, 271 N.Y. Supp. 891 (City C. 1934). 
worth discussing. He wrapped the problem up neatly in two sentences, although his second sentence seems to take back most of the assurance which the first sentence apparently confers on happy assignees of contract rights :

Where there has been an absolute assignment in good faith and for a valuable consideration of the whole interest of the assignor in a chose of action, the assignor's control over it ceases immediately after the assignment and notice, and he can do nothing thereafter to prejudice or defeat the rights of the assignee. It has been held, however, that the assignment of money to become due under an executory contract is stbject to the right of the anticipatory debtor to do whatever appears to be reasonably necessary to enable the assignor to perform the contract, and is also subject to the right of the original parties to rescind or modify the constract where such right is exercised in good faith, and not with intention to defraud the assignee. .1

The first sentence is supported with an impressive string citation of cases which, if tracked down, would have to do mostly with the proposition that, after notification, the obligor must pay the assignee and cannot get a discharge by paying the assignor. The second sentence is more modestly documented: reference is made to only two cases, Peden Iron \& Steel Co. v. McKnight tu and Homer v. Shaze. ${ }^{33}$

The two cases last mentioned involved a situation, once quite common in the construction industry, which the widespread use of surety bonds has rendered more or less obsolete. In each of the cases a subcontractor, having assigned the moneys to become due under his contract with the prime contractor, fell into difficulties. In Homer v. Shaw the subcontractor notified the prime contractor that he would be unable to complete the subcontract. The prime contractor, who had been notified of the assignment, then entered into a new arrangement under which the subcontract was rescinded and the original subcontractor was kept on as a supervisory employee of the prime contractor at a weekly wage. The assignee was not consulted about the new arrangement and did not consent to it. The Massachusetts court commented:

The parties while they could not modify to his prejudice the terms of the contract assigned without the plaintiff's [assignee's] consent, or by a

51. 5 C.J. 959-60. The two sentences survive in the revision, 6 C.J.S. 1152, although they have been separated by a few interpolated flourishes.

52. 128 S.W. 156 (Tex. Civ. App. 1910). For no discernible reason the C.J.S. revision drops the Peden case and cites in its place, Globe Indemnity Co. v. West Texas Lumber Co., 34 S.W.2d 896 (Tex. Civ. App. 1930). This switch was, on the whole, a retrograde step, since the Peden case was in point and the Globe Indemmity casc was not. The Globe Indemnity case was a priority contest between a surety company and a bank of the type referred to in note $\mathbf{5 7}$ infra. Judgment went for the bank, principally on the ground that the assignment to the surety company had been "merely conditional". (On "conditional assignments" see text at notes 7-14 supra.) The Globe Indcminity case cites Peden for the proposition that the obligor, even if it had notice of the assignment to the surety, could go on dealing with the contractor and his assignee, the bank. The $P_{\mathcal{E}} d e n$ case would seem to support judgment for the surety company rather than the bank (sce note 57 infra).

53. 212 Mass. 113,98 N.E. 697 (1912). 
secret fraudulent arrangement deprive him of the benefit of the assignment, were not precluded from entering into a new agreement if performance by the assignor had become impossible from unforeseen circumstances. ${ }^{54}$

In the Peden case the subcontractor and prime contractor, instead of purporting to enter into a new arrangement, continued under the original contract. However, the prime contractor, after having received notice of an assignment to a supplier, made further advances to the subcontractor to enable him to meet his payroll and other expenses. The Texas court, holding that the prime contractor was not liable to the assignee for the advances made to the assignor, ${ }^{05}$ commented that the rule that, after notification of an assignment, the "debtor deals with the assignor at his peril, and can do nothing that will adversely affect the interest of the assignees" was "too broad" and needed qualification. The qualification was set forth in language destined for the immortality of Corpus Juris:

[W] hen the existence of the assigned fund is dependent upon performance by the assignor of an executory contract, the anticipatory debtor may . . . do whatever reasonably appears to be necessary to enable the assignor to perform the contract. ${ }^{56}$

We may generalize the proposition which underlies cases like Peden and Homer v. Shaw in this way: an assignee of the proceeds of an executory contract takes subject to the right of the obligor to make further advances to the assignor, provided that such advances are necessary to enable the assignor to complete the performance of the contract and are so used. ${ }^{\text {or }}$ It makes no

54. 212 Mass. at 117, 98 N.E. at 698. In Homer v. Shaw, 177 MFass. 1, 58 N.E. 160 (1900), which involved the same transaction, the Court held that the assignee could not recover on a quantum meruit count. The second case was brought in contract.

55. That is, the prime contractor was allowed to deduct the aggregate of his advances to the assignor from the amount that, except for the advances, he would have owed the assignee.

56. 128 S.W. 156, 159.

57. The presence of a surety company which is obligated under its bond to take over performance of the contract on default obviously changes the situation in cases like Peden and Homer v. Sharo. However, the typical financing pattern in the construction industry calls not only for a surety who guarantees performance but for a bank which, at the outset, makes an enabling loan to help the contractor get started. Both surety and bank take assignments of moneys to become due under the contract to secure the surety's contingent liability and the bank's advance. The surety will also claim, if he is obliged to complete the contract, that, with respect to moneys which become payable under the contract after default, he is entitled to be "subrogated" to the rights of the defaulting contractor, or of his unpaid materialmen or, indeed, of the owner himself. This controversy between banks and surety companies has been a lively focus of litigation for the past twenty years.

Most of the cases since 1940 have involved contracts with the United States. There has been a good deal of recent law review discussion of the problem. The best contribution is Speidell, "Stakeholder" Payments Under Fcderal Construction Contracts: Payment Bond Surety vs. Assignee, 47 VA. L. Rev. 640 (1961). Since Professor Speidell wrote, the decision in Pearlman v. Reliance Ins. Co., 371 U.S. 132 (1962), may have tilted the 
difference whether the advances are made under the original contract or under a substituted contract after rescission of the original contract. While there has never been a great deal of litigation of this type, a respectable amount of authority can be found to support the proposition as we have stated it. ${ }^{68}$

Indeed authority can be found to support a much broader proposition, which might be put this way: the original contracting parties remain free to modify or indeed call off their arrangement whenever they have what the Code would call a "commercially reasonable" explanation for what they do and are not simply attempting to defraud the assignee. As an extreme instance, we may take the Nebraska court's conclusion in Babson $v$. Village of Ulysses. ${ }^{\text {to }}$ In 1921 the village entered into a contract with the Blue River Power Company to supply electric power to the village which the village would then itself distribute to retail customers. The village agreed to pay at specified rates for all the power used plus a fixed charge of $\$ 100$ per month : the purpose of the fixed charge was to amortize the cost of a transmission line which the Power Company had to build in order to carry out the contract. The contract was to run until 1940. Babson apparently owned all the stock of the Blue River Power Company. In 1925 the Blue River stock was sold to the United Light and Power Company, which assumed the contract with the village and continued to perform it. In connection with the purchase of the Blue River stock, United assigned to Babson, apparently as part of the consideration, the right to receive the $\$ 100$ monthly payment. The village, having been notified of the assignment, thereafter made the monthly payments to Babson. In 1930 the village decided to go out of the business of distributing electricity. At this

balance in favor of the surety companies. The Pearlman case did not involve priorities between bank and surety; however, in holding that the surety's subrogation claim could not be defeated by the contractor's trustee in bankruptcy, Justice Black used languago which the surety companies will no doubt find helpful in their continuing struggle with the banks. For present purposes, it is enough to say that when the surety is held to have a better right than the bank to retained percentages or a final progress payment, the result is quite like that in Peden and in Homer $v$. Shaw. In those cases the contractor obligor was preferred over the assignee with respect to advances made to the assignor which made possible the completion of the job. The surety who wins over the bank is preferred with respect to exactly the same kind of advances or expenses which he incurs in substitution for the obligor.

58. See, e.g., Stansbery v. Medo-Land Dairy, Inc., 5 Wash. 2d 328, 105 P.2d 86 (1940); St. Mary's Bank v. Cianchette, 99 F. Supp. 994 (D. Maine 1951); Fricker v. Uddo \& Taormina Co., 48 Cal. 2d 696, 312 P.2d 1085 (1957) ; St. Paul Fire \& Marine Ins. Co. v. Barnes Constr. Co., 59 Cal. 2d 691, 31 Cal. Rptr. 52 (1963).

There is a series of lower court New York cases which take a less charitable view of the obligor's power to make adjustments with the assignor. Recent examples of this view are Ives v. Mars Metal Corp., 23 Misc. 2d 1015, 196 N.Y.S.2d 247 (Sup. Ct. 1960) ; Associates Discount Corp. v. Commander, 40 Misc. 2d 782, 244 N.Y.S.2d 103 (Dist. Ct. 1963). These cases may reflect the New York common law rule on priorities between successive assignees of the same chose in action; see note 50 supra and accompanying text. See further the New York amendment to $\S 9-318(2)$ of the Code, note 72 infra.

59. 155 Neb. 492, 52 N.W.2d 320 (1952). 
point the Iowa-Nebraska Light \& Power Company had succeeded United as the other party to the contract. The village entered into an agreement with the Iowa-Nebraska Company under which the village sold its own distribution system to the company, and also granted the company a twenty-five year franchise to build and operate an electric power system. Both the company and the village took the position that the new arrangement rescinded the old contract. The village made no further payments to Babson, who eventually brought suit to recover the monthly payments of the fixed charge from 1930 to 1940 . The Court, holding for the village (and perhaps, by implication for the Iowa-Nebraska Company, which was not, however, joined as a defendant), said:

The assignment here was of payments of money to become due under an executory contract which the parties thereto were privileged to rescind or discharge entirely or to modify by agreement thus relieving each from the further obligations thereof in case of rescission or discharge and substituting the new ones in case of modification. ${ }^{60}$

It is true that the cases which the court cites in support of its somewhat extravagant proposition do not go quite that far.

The Babson case may call to mind the Depression cases previously discussed which held that requirements buyers were privileged to go out of business and cease having requirements. In the Babson opinion there is nothing to suggest that the village was motivated by anything except its own convenience and, conceivably, the possibility of lower rates from the Iowa-Nebraska Company. Mr. Babson seems to have been left holding the bag for the (presumably) half-amortized cost of the transmission line which his Blue River Company had built to serve the village in 1921 .

There is no intention of suggesting that the Babsors case is either "good law" or "the law". It is, however, a case - no doubt diligent research would turn up others like it - which financing assignees will do well to ponder.

\section{The "mortgage milking" cases}

Our next subject has usually been considered as a branch of property law. However that may be, the cases we are about to take up bear a distinct family resemblance to those which have been discussed in the preceding section.

In financing of real property which is put to a commercial use, a standard arrangement is, and long has been, that, in addition to a mortgage of the property, there will be, as further security, an assignment of rents. So long as there is no default on the mortgage, the mortgagor collects and keeps the rents

60. $155 \mathrm{Neb}$. at 497,52 N.W.2d at 324 .

The Nebraska court relied on Babson in deciding Mid-America Appliance Corp. v. Federated Finance Co., 172 Neb. 270, 109 N.W.2d 381 (1951). Consumers Afart assigned its accounts to Federated; the financing arrangement was "with recourse" and a reserve was set up to take care of losses. Thereafter Consumers Mart assigned to Alid-America its "right, title, and interest" in the reserve. Held, that Federated could charge the reserve for losses arising from accounts assigned to it after it had been notified of the assignment to Mid-America. 
without accounting for them to the mortgagee. If, after default, the mortgagec takes possession or secures the appointment of a receiver, the rents are collected under the assignment. It is sometimes said that the mortgagee, even before he has exercised his rights as assignee, has an equitable lien on or a pledgc of the future rents. ${ }^{61}$

The collapse of real estate values during the 1920's induced many mortgagors to engage in practices which became known as "milking". ${ }^{22}$ The mortgagor would enter into arrangements with his tenants under which the tenants would prepay the rent for a considerable period or the balance of the term; in return the tenants would receive concessions, such as a reduction in rent. The honest mortgagor would use the cash thus procured in an attempt to operate the property and stave off default. The dishonest mortgagor would use it to start a new life in fairer climes. In either event, when the mortgagee or his receiver moved in to collect the rents. they would find that the cow had already been milked - assuming, that is, that the tenants' arrangements with the mortgagor were binding on the mortgagee.

The basic assumption of all the case law on "milking" seems to have been that the right of the mortgagor and tenant to deal with each other, without consulting the mortgagee or getting his consent, was so obvious that, in the absence of fraudulent intent, it could not even be questioned. ${ }^{03}$ This was so even though the tenant had notice, actual or constructive, of the mortgage and the assignment of rents. It is interesting that this should have been the assumption when the question of the rights of the assignee to future rents was

61. A preliminary question is why such an arrangement is not invalid as a fratudulent conveyance under the rule of Benedict v. Rainer. Is there not, with respect to the rents which the mortgagor is allowed to collect and use for his own purposes, a "reservation of dominion inconsistent with the effective disposition of title and creation of a lien?" 268 U.S. 353, 363 (1925). There was, indeed, a moment in history when the Second Circuit, which had become the only true expounder of the Bencdict doctrine, seemed inclined to hold that Benedict was a rule of universal application and, specifically, that the assignment of rents under a real estate mortgage was invalid. Guinzburg v. D. A. Schulte, Inc., 91 F.2d 733 (2d Cir. 1937) ; McCance v. D. A. Schulte, Inc., 91 F.2d 733 (2d Cir. 1937). But cf. Smith v. D. A. Schulte, Inc., 91 F.2d 732 (2d Cir. 1937), following Sullivan v. Rosson, 223 N.Y. 217, 119 N.E. 405 (1918); In re McCrory Stores Corp., 73 F.2d 270 (2d Cir. 1934). However, the moment passed, the crisis abated and the Bencdict rulo became confined within the area of non-notification accounts receivable financing. In re New York, N.H. \& H.R.R., 25 F. Supp. 874 (D. Conn. 1938), discussed in text accompanying note 11 supra, may be taken as marking the end of the period during which it seened that Benedict might become "a rule of universal application". It has been a generation or more since a real estate mortgagee has had any reason to worry about the possible applicution of the great case of Benedict v. Ratner: since most real estate mortgagees appear never to have heard of the great case, that may be just as well.

62. See 2 Glenn, Mortgages \$ 183 et seq. (1943); Osborne, Mortgnges \& 158 (1951). The "milking" litigation stimulated a considerable amount of activity in the law reviews during the 1930's. The following brief discussion relies on Glenn and Osborne.

63. See particularly the discussion by Guenn, op. cit. supra note 62. Professor Osborne is somewhat less categorical than Glenn. 
approached from the property law side. Surely the instinctive assumption of most lawyers, when the apparently identical problem of the rights of an assignee to the proceeds of an executory contract is approached from the contract law side, is the reverse - although, as we have suggested in the preceding section, the contract law assumption rests on a fimsy foundation.

On the assumption that good faith adjustments between mortgagor and tenant could not be questioned, the "milking" cases elaborately considered what circumstances might amount to fraud. One proposition that emerged from the discussion was that there was no fraud when the money which the tenant paid the mortgagor was used in the maintenance or operation of the property. In Grether v. Nick, which came to be cited as a leading case, the Wisconsin Court, although the opinion was broadly written, was dealing with such a state of facts. ${ }^{64}$ Cases of this type are not unlike the contract cases in which the obligor's advances to enable the assignor to perform his contract have been protected against the assignee's claim. ${ }^{65}$ On the other hand, the tenant stood to lose in the situation where the money he had paid the mortgagor was diverted to the mortgagor's own uses. Glenn argued in his treatise on mortgages that the very fact of prepayment by a tenant was so "abnormal" that the mortgagor's fraud should be imputed to the tenant even if the latter was subjectively innocent and that the only exception allowed should be where the money was used for upkeep of the building. ${ }^{60}$ It was not entirely clear that all courts were, to that extent, mortgagee-oriented, although a line of New York cases seemed to be moving in that direction. ${ }^{67}$ The question was left unresolved when the recovery of real estate values and the onset of what has proved to be a long period of inflation brought the "milking" litigation to an end.

\section{The Modification Problem Under the Code - Section 9-31S(2)}

Section 9-318(2) of the Code provides:

So far as the right to payment under an assigned contract right has not already become an account, and notwithstanding notification of the assignment, any modification of or substitution for the contract made in good faith and in accordance with reasonable commercial standards is effective against an assignee unless the account debtor has otherwise agreed but the assignee acquires corresponding rights under the modified or substituted contract. The assignment may provide that such modification or substitution is a breach by the assignor.

64. 193 Wis. 503, 215 N.W. 571 (1927). GLENN, op. cit. supra note 62, at $\S 183.1$, cites Grether v. Nick as holding, broadly, that "a receiver could not collect rent from a tenant who had paid in advance for the whole term," but argues that the case could (and should) "have gone off on the point that the prepaid rent actually went into improvement of the property." A broad reading of Grether v. Nick, Glenn suggests, "would justify every type of 'milking' to which the mortgagor might resort."

65. See the cases discussed in the text following note 53 supra.

66. GLENN, op. cit. supra note 62 , at $\$ 183.1$.

67. The Prudence Co. v. 160 West 73d St. Corp., 260 N.Y. 205, 183 N.E. 365 (1932); Bank of Manhattan Trust Co. v. 571 Park Ave. Corp., 263 N.Y. 57, 185 N.E. 156 (1933); Colter Realty, Inc. v. Primer Realty Corp., 262 App. Div. 77, 27 N.Y.S.2d 850 (1941). 
"So far as the right to payment under an assigned contract right has not already become an account ..."

There is first of all a definitional difficulty. The terms "account", "contract right" and "general intangibles" are defined in section 9-106:

'Account' means any right to payment for goods sold or leased or for services rendered which is not evidenced by an instrument or chattel paper. 'Contract right' means any right to payment under a contract not yet earned by performance and not evidenced by an instrument or chattel paper. 'General intangibles' means any personal property (including things in action) other than goods, accounts, contract rights, chattel paper, documents and instruments. ${ }^{68}$

Thus "contract rights" are future rights to payment under any kind of contract, during the period before performance. "Accounts" are the same rights after performance, provided that they arise out of contracts for the sale or lease of goods or for the rendition of services. Rights to the payment of money which are earned under other kinds of contracts do not become "accounts", if the definitions are read literally (as no doubt definitions are meant to be read); they must therefore become "general intangibles", which is used as a residual term. This slippage between the clefinitions of "contract rights" and "accounts" was the result of drafting inadvertence. With respect to the preambulary language of section 9-318(2), there was no intention of drawing an involved or nonsensical distinction between rights to payment which arise when goods are sold or leased or services are rendered and rights to payment which arise from performance of other types of contracts. The preamble ought to have read: "So far as the right to payment under an assigned contract has not been earned by performance...." We shall deal with it as if it so read.

The evident meaning of the preamble is that the rule of the subsection does not apply once the right to payment has become fixed by performance. After the goods have been sold or the services rendered, it is too late for the contracting parties to vary their contract or agree to a rescission: the assignee's rights have, so to say, vested. There is unfortunate language in the "account" definition which might be read to mean that, with respect to a lease of goods, the assignee's rights would vest when the lease was executed. We have, however, decided to read the preamble as if it referred to rights which have "not been earned by performance". There is surely no reason to distinguish between an executory lease and all other kinds of executory contracts. ${ }^{00}$ We shall as-

68. The term "account debtor" which is used in \$ 9-318(2) may sound as if it mcant a "debtor" who owes an "account". The term is, however, defined ( $\$ 9-105)$ to include any contract obligor: "'Account debtor' means the person who is obligated on an account, chattel paper, contract right or general intangible." We shall use the terms "account debtor" and "obligor" interchangeably.

69. There is, of course, venerable authority to the effect that, under property law, a lease is executed when the leasehold interest is transferred to the lessee, just as, under pre-Code sales law, a contract of sale was "executed" when the "property in the goods" was transferred to the buyer. The Code expressly rejects the "property" concept and its consequences as a matter of sales law (see, e.g., §§ 2-401, 2-509). There is no comparablo 
sume, therefore, that the rule does apply to future, as yet unearned, payments under leases.

"Notwithstanding notification of the assigmment . . ."

This means clearly enough that the rule of the subsection applies despite notification. It might also be taken to mean that the rule applies in the absence of notification. It will be noted that the subsection makes "modifications" and "substitutions" effective against assignees, subject to the limitations of "good faith" and "reasonable commercial standards". There seems to be no reason why a contract obligor should be held to the observance of reasonable commercial standards or any other standards vis-a-vis an assignee of whom he has never heard. Until he knows of the assignment, he should remain free to deal, for all purposes, with the other contracting party. Subsection (3) of section 9-318 makes it clear that the account debtor may pay the assignor until he has been notified and directed to pay the assignee. It might have been better if section 9-318(3) had referred not only to payment but to dealing with the assignor generally. Even so, however, it seems reasonably clear that section 9-318(2) refers only, so far as the limitations on the account debtor's freedom of action are concerned, to the post-notification situation.

"Unless the account debtor has otherwise agreed . . ."

Under this provision the assignee may protect himself against subsequent modifications and substitutions by extracting from the account debtor an agreement that he will not seek to vary the contract by dealing with the assignor without the assignee's consent.

The account debtor might make such an agreement with the assignee at the same time he enters into the contract with the assignor. In that case, no one would doubt that the consideration which supports the contract would also support the account debtor's promise not to vary the contract without the assignee's consent. Suppose, however, that the agreement with the assignee is made after the contract is entered into. If it is made simultaneously with the loan, the assignee's promise to make an advance to the assignor could be used as consideration for the account debtor's agreement not to modify. Even if that were not done, the assignee could argue that the account debtor would be estopped to deny his agreement if it appeared that an advance was made in reliance on it. The hardest case would be one in which the account debtor's agreement not to modify was made not only after the contract but also after the advance. Unless it could be argued that such an agreement is binding without consideration, ${ }^{70}$ the assignee's best hope would be an estoppel argu-

express language of rejection with respect to leases, but, on the other hand, there is no indication that the contract-oriented draftsmen of the Code meant to perpetuate the ancient rule of property law.

70. Under, or by analogy from, such Code provision as \$ 2-209 or such non-Code legislation as N.Y. General Obligations Law $\$ \S$ 5-1101-13 (formerly N.Y. Pensoral PROPERTY LAW \& 33). 
ment: in reliance on the agreement, the assignee refrained from exercising his rights under the security agreement, and so on.

It should be pointed out that the term "agreement" is very broadly defined in the Code [section 1-201(3)]. It means "the bargain of the parties in fact as found in their language or by implication from other circumstances . . . ." The section 9-318(2) provision does not in terms require that the account debtor's agreement not to modify be express or in writing or, indeed, made with or directed to the assignee. A broad construction of "agreement" could obviously be used to limit the freedom of account debtor and assignor to vary the contract.

"The assignment may provide that such modification or substitution is a breach by the assignor."

"Breach" presumably means the same thing as "default".71 If the debtor in the security transaction (who is the "assignor" under section 9-318) has covenanted not to modify his assigned contract rights without the secured party's ["assignee's"] consent and nevertheless does so, then he is in defatilt under his security agreement ["assignment"] and the secured party may exercise whatever rights he has by contract or under Part 5 of Article 9. If his only security is the assigned contract rights which have been "effectively" modified, that may be cold comfort to him. On the other hand, if his security also includes the assignor's factory, or its machinery, he may be in a position not only to declare a default but to make the assignor and account debtor think twice about their "modification".

Note that this sentence applies to the adjustments which are made "in good faith and in accordance with commercially reasonable standards" and are, consequently, "effective" against the assignee. Would such adjustments constitute an event of default under the security agreement in the absence of an express provision to that effect? Or would the assignee be remitted to his "corresponding rights" under the contract as adjusted? While the statutory text may not be entirely clear, it can be fairly read to mean that the assignor's participation in an "effective" adjustment would be a default only if the security agreement expressly made it so. No doubt an "ineffective" or bad faith adjustment would be a default in any case. Such a construction puts an assignee, who has not protected himself by an express clause in the security agreement, in a difficult situation. A secured party who exercises his defatult rights - who, for example, takes possession or disposes of collateral when no default has occurred - will be treated as a wrongdoer under Article 9 as he has been under all pre-Code law. If the existence of a default depends

71. Cf. § 9-311:

The debtor's rights in collateral may be voluntarily or involuntarily transferred . . . notwithstanding a provision in the security agreement prohibiting any transfer or making the transfer constitute a default.

Under § 9-501(1) :

When a debtor is in default under a security agreement, a securce party has tho rights and remedies provided by this Part [i.e. Part 5 on Default]. ... 
on whether or not assignor and account debtor have acted in good faith and observed reasonable commercial standards, a secured party will be well advised to walk warily if he wants to avoid a judgment in conversion.

If the adjustment entered into by the assignor and account debtor does constitute a default, the secured party seems to have an election of courses of action. He can accept the "corresponding rights" which he acquires under the adjusted contract. Or he can declare a default. Acceptance of his "corresponding rights" would seem to be a waiver of what would otherwise be an event of default. At this point the statutory text is a good deal less than satisfactory. It does not require the account debtor or the assignor to notify the assignee of any adjustment - which would seem to be a reasonable procedure and could easily have been made a condition of the "effectiveness" of the adjustment against the assignee. Nor does it require the assignee to make his election within any specified period of time. Can he lie back for a month or two or three - to see how things are going before he decides whether to go along with the adjusted contract or to declare the loan in default and exercise his rights against the collateral? The courts are obviously going to have their work cut out for them in filling in the detail of this vaguely outlined provision.

\section{The scope of the modification power}

Now we come to the heart of the matter: subject to the limitations which have been discussed,

any modification of or substitution for the contract made in good faith and in accordance with reasonable commercial standards is effective against an assignee ... . ${ }^{72}$

72. U.C.C. $\$ 9-318(2)$. In New York this provision has been amended to read: any modification of or substitution for the contract made in good faith, in accordance with reasonable commercial standards and without material adverse effect upon the assignee's rights under or the assignor's ability to perform the contract is effective against an assignee....

The amendment was apparently made in response to a suggestion of the New York Law Revision Commission. See Unifords Comarercial Code, New York Awnorations and Report of Coaraission on Uniforar State Laws to Legrslature of New Yosk State (1961), which comments with respect to the official or uniform text of $\S 9-318(2)$ :

The freedom of modification and substitution allowed here is for the protection of the obligor and would apparently modify existing law or at least existing policy. See Collens v. Philipsborn's Inc., 209 App. Div. 483, 205 N.Y.S. 210 (1st Dept. 1925), aff'd, 239 N.Y. 611, 147 N.E. 217 (1925) ; Mfadison Industrial Corp. v. Elisberg, 152 Misc. 167, 271 N.Y.S. 891 (1934). Compare Personal Property Law, $\S 41(3)$.

On the pre-Code state of New York law, and on the ancestry of the Elisberg ease, see notes 50 \& 58 supra and accompanying text. The Collens case closely resembles the Elisberg case referred to in note 50 supra. N.Y. GeNeraL ObLIGations Law $§ 13-105$, formerly N.Y. Personal Property Law \& 41(3), has nothing to do with the problem of modification and substitution.

The evident purpose of the New York amendment is to put the assignee in control of the situation. It is impossible to tell how much play the courts will find in "material" and 
The Comment casts some light on what the draftsmen of this deceptively simple statement may have had in mind and offers a convenient starting point for discussion. After remarking that the rule stated in section 9-318(2) "may do some violence to accepted doctrines of contract law," the Comment goes on to say that the rule is "nevertheless ... sound and necessary . . . in view of the realities of large scale procurement." As an example of these "realities" the Comment hypothesizes the decision of a "government agency to cut back or modify existing contracts" and notes that, after termination or modification of the prime contracts, "comparable adjustments must be made promptly in hundreds and even thousands of subcontracts lying in many tiers below the prime contract." The rule of section 9-318(2) "gives the prime contractor (the account debtor) the right to make the required arrangements directly with his subcontractors without undertaking the task of procuring assents from the many banks to whom rights under the contracts may have been assigned." While the statutory text spealss only of "modifications" and "substitutions", the Comment leaves no doubt that outright terminations or rescissions were thought of as being within the rule of the subsection.

The situation which the Comment uses as an illustration was a familiar one during the period immediately following World War II when both the text of section 9-318(2) and the explanatory Comment were written. In that context the rule of the subsection makes obviously good sense. There is, of course, nothing in the statutory text (unless the reference to "reasonable commercial standards" could be so taken) which limits the rule either to "the realities of large scale procurement" or to cutbacks and modifications initiated, on the prime contract level, by a government agency.

If we assume that the rule is not limited to the termination of government contracts after World War III, we may start with the proposition, which the Comment suggests, that the rule must apply to cases of some types in which the adjustment is sought by the account debtor (buyer, lessee or obligor) and is presumably of benefit to him. We shall then consider whether the rule may

"adverse". Does a contract adjustment, for example, have an "adverse effect upon the assignee's rights" if it increases the probability that the contract will be performcd while, at the same time, it decreases the amounts that will become payable?

Permanent Editorial. Board for the Uniformi Commercial Code, Rerort No. 1 (1962), disapproves of the New York amendment with the comment that:

The New York limitation in subsection (2) is necessarily implied from the applicable requirements of good faith and observance of reasonable commercial standards. Material modifications adversely affecting the assignee's rights or the assignor's ability to perform, without the assignee's consent, would not conform to these standards. Thus the proposed New York change is unnecessary.

In the light of our discussion, it is suggested that the New York amendment or "limitation" (which may have been unwise) should not be dismissed as "unnecessary" on the ground that the official text of $\$ 9-318(2)$ means the same thing as the New York version. To the present writer the two versions seem to mean quite different things.

At the date of writing the official text of $\S 9-318(2)$ has been enacted without change in all Code states except New York. 
also apply to cases where the adjustment is sought by, and is presumably of benefit to, the assignor (the seller, lessor or, as we have earlier described him, the performing party).

In an earlier section we noted the ambiguous attitude which the sales article of the Code takes toward the applicability of the doctrine of frustration to buyers under sales contracts as well as the apparent codification of the depression cases which held that buyers under requirements contracts could "in good faith" go out of business and thus cease to have any requirements. ${ }^{73}$ If a buyer or other paying party could take advantage of the frustration doctrine or if a requirements buyer was within the scope of the "going out of business" cases, he would of course have a "defense" under the contract which could be asserted against the assignee under section 9-318(1), and would not need the additional protection of section 9-318(2). Let it be assumed, however, that the situation is not clear-cut (as, indeed, it never will be). For illustration we may take the case of a buyer under a long-term sales contract, but the discussion will apply to any type of contract. The buyer, whether he has agreed to buy fixed quantities or his requirements, finds himself in a position where further performance of the contract will be unprofitable to him. The change of circumstance, let us further assume, is not sufficiently great to give him a "defense" if the seller insists on either performing the contract or suing for damages. But it is easy to imagine situations in which the seller could be persuaded to enter into a rescission or to adjust the contract in the buyer's favor. (It should not be lost from sight that much current financing of this type involves a high-credit buyer and a low-credit seller who is to a greater or less degree under the buyer's control. $)^{\text {7t }}$ Can it not be plausibly argued that such a rescission or readjustment is entirely within the realms of "good faith" and "reasonable commercial standards"? Is a buyer in "bad faith" who, by agreement with his seller, gets out of a losing contract? Does a seller fail to observe "reasonable commercial standards" if he forbears to insist on the last ounce of his pound of flesh? Furthermore, it is clear that section 9-318(2), if it is to be given any meaning at all, must give seller and buyer power to deal with each other, without seeking the assignee's consent, in situations where the buyer, although he may reasonably want to get out of his contract, does not have a "defense". Unless section 9-318(2) covers more than "defenses", there is no need for it at all, since section 9-318(1) already makes all defenses available against an assignee.

We may conclude that, to an unknowable extent, section 9-318(2) authorizes an obligor to rescind or adjust his contracts by agreement with his assignor even when he is without a defense to the contract. The unknowable will become known only in the light of litigation. We suggested in an earlier part of our discussion that a discernible trend of contract law over the past

73. See text following note 47 sipra.

74. See the text at note 3 supra. 
half century has been a broadening or liberalization of the discharge rules. ${ }^{70}$ Section 9-318(2) might be taken as consistent with such a trend. By its very presence it operates to blur the edges of subsection (1) on defenses.

Reversing the situation, is there any reason why the rule of section 9-318(2) should not apply to rescissions and readjustments which are initinted by the assignor (the performing party), presumably for his benefit? There is nothing in the text of the subsection which limits it to situations where the account debtor is, so to say, the moving party, although that is the only type of situation which is referred to in the Comment. And the available analogies from the pre-Code case law furnish us with illustrations of adjustments between obligors and assignors, entered into for the assignors' benefit, which have been held good against non-consenting assignees. There are, for example, the cases which have held that obligors, who have been notified of an assignment and directed to pay the assignee, may nevertheless make further advances to the assignor which are necessary to enable him to perform his contract. ${ }^{70}$ And there are the so-called "milking" cases which held that, apart from fratud, tenants could make pre-payment agreements with their mortgagor-landlords which would be binding on mortgagees when they or their receivers entered into possession of the mortgaged property to collect the rents. ${ }^{77}$

Unless the meanings of "good faith" and "reasonable commercial standards" have suffered a sea change, there seems to be no reason to doubt that section 9-318(2) codifies Honer v. Shazv, Grether v. Nick, their successors and ana* logues. ${ }^{78} \mathrm{~A}$ hypothetical illustration may be helpful. Assume an assignment of proceeds of a long-term contract. The assignee, relying on the Code's abolition of the rule of Benedict $v$. Ratner, ${ }^{79}$ allows the account debtor, who has been notified of the assignment, to make his payments to the assignor. The loan agreement requires periodic payments of principal and interest but, so long as those are kept up, the assignor may use the contract proceeds as he will. Assume now that the assignor, being hard-pressed, agrees, in consideration of a present advance or a pre-payment by the account debtor, to make contract adjustments in the account debtor's favor: he will redice the price of goods or will do more work for the same price or whatever may be imagined. The argument for the "effectiveness" of such an adjustment, designed to re-

75. See the text at note 44 sipra.

76. See the cases cited in note 58 supra and the accompanying text.

77. See text following note 63 supra.

78. Homer v. Shaw is discussed in the text following note 53 supra; Grether v. Nick in note 64 supra and accompanying text.

The Massachusetts annotation to § 9-318(2) [MAss. Gen. LAws ANN., Ch. 106] says: The freedom of modification and substitution allowed by subsection (2) would change Massachusetts law. Under present law the original parties could not modify the contract to the prejudice of the assignee without his consent. Homer v. Slaw, 212 Mass. 113, 117, 98 N.E. 697 (1912).

Evidently the author of the Massachusetts annotation had a somewhat different interpretation of Homer v. Shaw from that which has been put forward here.

79. See text following note 5 supra. 
lieve a hard-pressed assignor, is surely quite as plausible as the argument for the effectiveness of adjustments designed to relieve hard-pressed obligors from the consequences of unprofitable contracts. Indeed the argument that persuaded the Massachusetts court in Homer $\%$. Shaw might be equally persuasive to a court construing section 9-318(2): if the adjustment had not been made, it might have been "impossible" for the assignor to perform his contract at all and in that case there would have been nothing for the assignce anyhow. ${ }^{80}$

We may therefore conclude that the adjustments which section 9-318(2) authorizes may be for the benefit of either assignor or account debtor. On the assignor's side, as on the account debtor's side, litigation will be required to translate the meaningless abstractions of "good faith" and "reasonable commercial standards" into something like concrete reality. Such abstractions take on meaning only in the light of a well-nourished current of case law: here the precedents, such as they are, are shadowy, inconsistent and confused.

Rights of the Assignee

Section 9-318(2) provides that "the assignee acquires corresponding rights under the modified or substituted contract ..." With this provision the Code moves into unexplored territory. The venerable slogan that "courts do not make contracts for the parties" will evidently no longer serve the court which may be confronted with the task of deciding exactly what rights an assignee acquires under an effective modification or substitution and how those rights are to be enforced. Neither section 9-318(2) nor the Comment offers any suggestions about how the task should be carried out. No doubt the draftsmen were wise in refraining from speculation on the proper way of translating this general proposition into the specific reality of a judicial decree.

The "corresponding rights" provision operates as still another limitation on the freedom of assignor and account debtor to deal with each other without taking the assignee's wishes into consideration. Even if they have cleared the hurdles of "good faith" and "reasonable commercial standards", they find the assignee, like the Old Man of the Sea, still with them, undislodged and, it may be, heavier than ever. Since the assignor and account debtor cannot go on dealing with each other free of the assignee's rights, no matter how "effective" the modification or substitution may be, they will be well advised to make any necessary contract adjustments in consultation with the assignee. If they fail to secure his consent, they will be buying a law suit, the outcome of which will be in the highest degree unpredictable.

The modification of the original contract may arise out of a situation in which the account debtor would have had a "defense" under the original contract, which would have been available against the assignee under section 9-318(1). Or out of one in which there was no defense. In any case, if the parties have

80. Indeed, it might not be impossible so to construe $\$ 9-318(2)$, even as amended in New York. See note 72 supra. 
agreed to go forward under modified terms without resorting to litigation, it will rarely be clear whether there would have been a defense or not. The relationship between section 9-318(1) and section 9-318(2) is by no means clear. It could perhaps be argued that the "corresponding rights" provision of section 9-318(2) should not apply to new arrangements entered into following a default by the assignor in the performance of the original contract. In such a case, the argument would run, the account debtor could have terminated or rescinded the executory portion of the contract without liability to either assignor or assignee. If he did so and subsequently entered into a new, independent arrangement with the defaulting party, how could the assignee of the proceeds of the original, now abandoned, contract claim "corresponding rights" under the new arrangement? This line of argument, if pursued far enough, can get us into uncomfortably deep waters. If the new arrangement is far enough removed, in time or in subject matter, from the original contract, it may be assumed that the "corresponding rights" claim would fail. On the other hand, if the new arrangement follows hard on the heels of the original contract and deals roughly with the same subject matter, then it seems that the assignee should be entitled to his "corresponding rights" whether or not the account debtor could claim or prove that he would have had a defense if sued on the original contract. Certainly section 9-318(2) draws no such distinction. It will never be clear, at the time the modification or substitution is agreed to, whether there was a defense or not. The only thing that will be clear is that, despite difficulties, the parties decided to go forward. That being so, the assignee who, by hypothesis, financed the original transaction and has not yet been paid, should be able to claim under the new arrangement. We may conclude that the existence or non-existence of a section 9-318(1) defense should be irrelevant to an assignee's claim for "corresponding rights" under section 9-318(2).

If, instead of going forward under a new arrangement, the account debtor and assignor agree to a rescission of the original contract, where does the assignee stand?

We may assume, in the first instance, that the account debtor agreed to the rescission under circumstances in which he could not have been sued on the original contract: because of the assignor's breach or because of discharge for some other reason he would have had a defense, and might indeed have had a claim for damages. In such a situation the assignee has nothing to complain of: he is not injured by the rescission and may even be benefited by it if the account debtor is giving up a possible claim for damages against the assignor. A more interesting assumption is that the assignor agreed to the rescission under circumstances in which the account debtor had not been discharged from the contract, had no defense, and would have been liable in an action for damages if he had repudiated the executory portion of the contract. 
A preliminary question is whether, under the general law of contracts, an assignment of proceeds carries with it the right to sue for repudiation or anticipatory breach by the contract obligor. That the assignee should have such a right, particularly in a case where he has made an advance to the assignor in reliance on the account debtor's going through with his part of the contract, seems a reasonable assumption. Nevertheless, there is little or no authority directly in point and no discussion of the problem in the treatises. ${ }^{81}$ If we assume that a petition in bankruptcy is filed against the assignor, his trustee in bankruptcy could plausibly argue that the right to damages against the repudiating account debtor had not passed with the assignment but remained an asset of the estate. As a safeguard against such an argument, a secured party whose collateral includes contract rights might well specify in his security agreement that the assignment includes the right to sue the account debtor not only for sums earned by the assignor's performance but also for damages resulting from the account debtor's wrongful repudiation of the contract.

Does the "corresponding rights" provision of section 9-31S(2) have any bearing on the assignee's claim, following a rescission? Although section 9-318(2) talks only of "modifications" and "substitutions", it can, and probably should, be construed to cover rescissions as well. ${ }^{82}$ Let us assume, for the purposes of the argument, that it does. Now, if the rescission is "effective" against the assignee under section 9-318(2), he surely has no possible claim against the account debtor. If the assignor has received consideration for entering into the rescission agreement, the assignee could reasonably claim that he had acquired "corresponding rights" in whatever the assignor had received, but the account debtor would be off the hook. Assume, however, that the rescission is ineffective against the assignee because it founders on the reefs of good faith and reasonable commercial standards. The "corresponding rights" provision of section 9-318(2) is not directly applicable but could perhaps be used as a solvent for common-law ambiguities. Section 9-318(2) protects the assignee, so far as may be possible, even against good faith and commercially reasonable adjustments. When a rescission is ineffective against an assignee, it would be consistent with the policy of the "corresponding rights" provision to give him the benefit of whatever cause of action the assignor, apart from the rescission, had against the account debtor.

We have been discussing the assignee's rights on the assumption that only the original parties to the financing transaction are involved. Against third parties such rights might be of doubtful worth. Under current Supreme Court doctrine it seems too plain for argument that an assignee's claim to "corres-

81. See the discussion in the text following note 35 stipra, on the obscure state of law with respect to whether a buyer, who has been notified of an assigument, should deal with the seller or the seller's assignee if he rejects goods tendered under the sales contract.

82. See text following note 72 supra. 
ponding rights" would lose to an intervening federal tax lien. ${ }^{83}$ And in the assignor's bankruptcy a "corresponding rights" claim might well be vulnerable to an attack under section 60 of the Bankruptcy Act. If a second assignee came in to finance a contract substituted for the original contract, a novel problem of priorities would be presented whose resolution might be doubtful. The pursuit of these chimeras would, however, overburden an already overlong piece: we may merely note that our story would not be at an end even if we were to conclude that section 9-318(2) returned a clear and certain answer to all the questions that might be put concerning the relationship of assignor, assignee and account debtor inter, as the old phrase has it, sese.

\section{ConcLusion}

Alexander Pope once cautioned his readers:

Be not the first by whom the new is tried

Nor yet the last to lay the old aside.

With respect to lending practices, the first piece of advice is, on the whole, sounder than the second.

Contract rights financing is risky business. A prudent assignee who gives thought to his status vis-a-vis trustees in bankruptcy and the United States in its capacity of collector of delinquent taxes might well conclude that the difference between an assignee of contract rights and an unsecured creditor is not great. And, even if death (which, in its corporate form, is called bankruptcy) and taxes be put to one side, the assignee's rights against the contract obligor are not as firmly fixed as most assignees would like to think they are.

Our review of the pre-Code case law suggests that there has long been a curious gap between what most lawyers may instinctively assume to be "the law" and what courts have in fact done in the scattered cases that have come before them. The inarticulate premise that underlies the judicial reaction may have been expressed by an English judge nearly a century ago:

... I cannot bring my mind to think that this doctrine [of "equitable assignment"] should be extended so as to prevent the parties to an unfulfilled contract from either cancelling or modifying, or dealing with regard to it in the ordinary course of business. I quite agree that they ought not to be allowed to act mala fide for the purpose of defeating an equitable assignee; but if what they do is done bona fide and in the ordinary course of business, I cannot think their dealings ought to be impeded or imperilled

83. The Supreme Court doctrine, briefly summarized, is that only a "choate" lien or security interest will prevail over a federal tax lien which has arisen under 26 U.S.C. $\$ \S 6321-23$ or a federal claim for priority under $\$ 3466$ of the Revised Statutes (31 U.S.C. § 191). In order to be "choate" the lien or security interest must be "certain as to amount, identity of the lienor [and] the property subject thereto ....", United States v. City of New Britain, 347 U.S. 81,86 (1954). Without going into detail, it is sufficicnt for present purposes to say that a "corresponding rights" claim under $\S 9-318(2)$ would be uncertain, and therefore inchoate, with respect to both "amount" and "property". Sec United States v. Pioneer American Ins. Co., 374 U.S. 84 (1963). 
by this doctrine .... If they cannot modify it [their contract], it seems to me to denote a state of slavery in business that ought not to be suffered; but I apprehend the parties to the contract can modify it. ${ }^{8 t}$

Perhaps, the reluctance of courts to carry the implications of assignment theory to their apparently logical conclusion reflects the feeling that business decisions should be left to businessmen and not given over to bankers and money-lenders merely as a deduction from the premise that intangible claims have become capable of effective transfer.

The Code, and in particular the provisions of section 9-318(2), may not do as much "violence to accepted doctrines of contract law" as the author of the Code Comment seems to have believed they did. ${ }^{85}$ Indeed, the Code assignee of contract rights may, in the light of the "corresponding rights" provision of section 9-318(2), be somewhat better off than his pre-Code counterpart. Even so, however, his security is far from being the best.

Recent professional discussions of contract rights financing teach a useful lesson $:^{86}$ if the essential security for a loan is an obligor's promise to pay for future performance, an assignment of the performing party's rights is not enough. A lender, who wants the substance and not merely the form of security, will see that, in one way or another, the obligor's duty to pay will run directly to him. Amateurs, who may be tempted to experiment with lending on the security of executory contracts, will do well to follow the professional example.

84. Britt, L.J., in Brice v. Bannister, L.R. 3 Q.B.D. 569, 579-80 (1878). The facts of the case were almost identical with those in Peden Iron \& Steel Co. v. AreKnight, and Homer v. Shaw, discussed in the text following notes $52 \& 53$ supra. There was a contrat to build a ship between Bannister (buyer) and Gough (shipbuilder). Gough assigned proceeds of the contract to Brice, who notified Bannister. Thereaster Gough fell into difficulties and Bannister made further advances to him which, under the assignment, should have gone to Brice. Britt felt that judgment should have gone for Bannister, the obligor (as the judgments in the two American cases did in fact go), but the two other judges who made up the Court of Appeal disagreed and judgment was given for Brice, the assignec. Brice v. Bamister suggests that English law would develop more favorably from the assignee's point of view than did American law. However, the case seems to have been forgotten in its own country: it is not cited in the current editions of Critrs; Co:mrncts (22d ed. 1961) or CHeshire \& Fifoot, Law of Contract (6th ed. 1964). The English treatises, like their American counterparts, ignore the problem of contract modification after an assignment of proceeds.

85. See text following note 72 supra.

86. See the articles by Gustin, Wilkinson and Coogan cited in note 2 stpra and the following discussion in the text. 